Uili norden

Public-Private Partnerships for Climate Finance

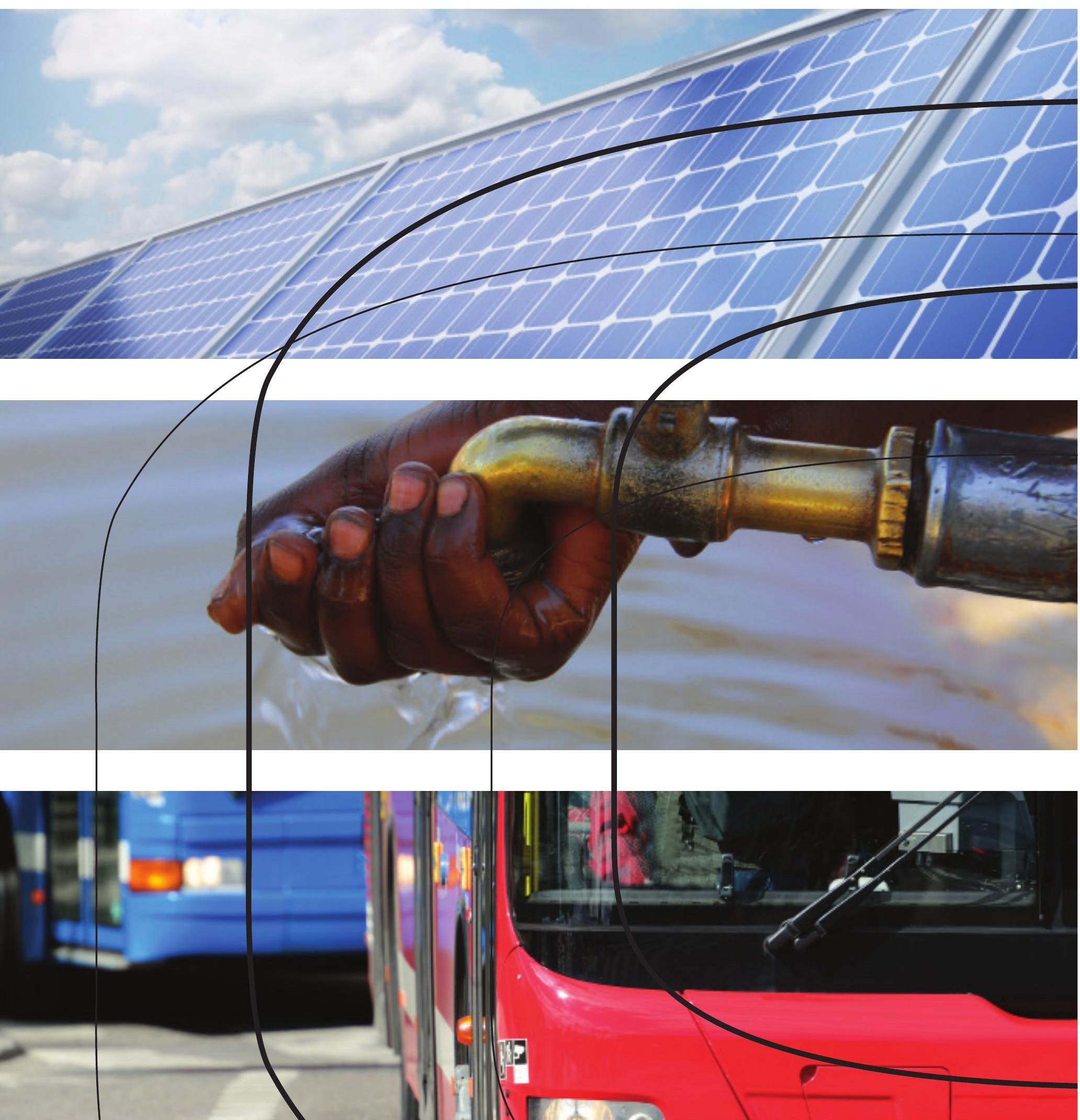



Uli norden 



\section{Public-Private Partnerships for Climate Finance}

Ann Gardiner, Matthieu Bardout, Francesca Grossi and Sandrine Dixson-Declève 
Public-Private Partnerships for Climate Finance

Ann Gardiner, Matthieu Bardout, Francesca Grossi and Sandrine Dixson-Declève

ISBN 978-92-893-4394-7 (PRINT)

ISBN 978-92-893-4395-4 (PDF)

ISBN 978-92-893-4396-1 (EPUB)

http://dx.doi.org/10.6027/TN2015-577

TemaNord 2015:577

ISSN 0908-6692

(C) Nordic Council of Ministers 2015

Layout: Hanne Lebech

Cover photo: Imageselect

Print: Rosendahls-Schultz Grafisk

Copies: 20

Printed in Denmark

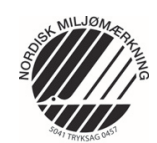

19. UNIVERSITYOF

ECOFYS

SUSTAINABILITY LEADERSHIP

This publication has been published with financial support by the Nordic Council of Ministers. However, the contents of this publication do not necessarily reflect the views, policies or recommendations of the Nordic Council of Ministers.

www.norden.org/nordpub

\section{Nordic co-operation}

Nordic co-operation is one of the world's most extensive forms of regional collaboration, involving Denmark, Finland, Iceland, Norway, Sweden, and the Faroe Islands, Greenland, and Åland.

Nordic co-operation has firm traditions in politics, the economy, and culture. It plays an important role in European and international collaboration, and aims at creating a strong Nordic community in a strong Europe.

Nordic co-operation seeks to safeguard Nordic and regional interests and principles in the global community. Common Nordic values help the region solidify its position as one of the world's most innovative and competitive.

\section{Nordic Council of Ministers}

Ved Stranden 18

DK-1061 Copenhagen K

Phone (+45) 33960200

www.norden.org 


\section{Contents}

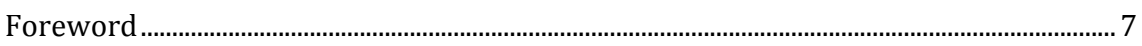

Introduction ................................................................................................................................

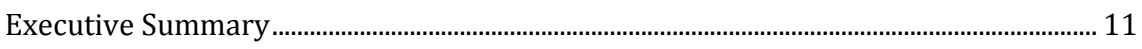

1. Public-Private Partnerships for Climate Finance.................................................................. 17

1.1 Climate finance .................................................................................................................. 17

1.2 Public-private partnerships .................................................................................

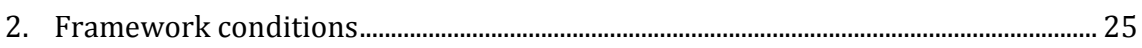

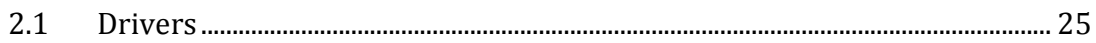

2.2 Enabling Environment................................................................................................. 27

2.3 Risks and barriers ............................................................................................................. 27

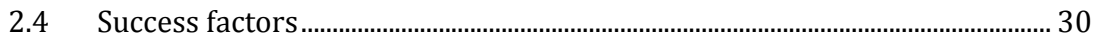

2.5 Paris and beyond: Prospects for the future? ………………………………….... 31

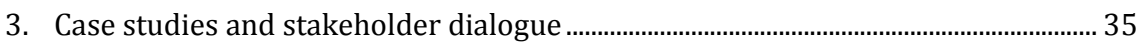

3.1 Case studies.................................................................................................................. 35

Insights from stakeholders ........................................................................................ 39

4. Discussion and key learnings.............................................................................................. 41

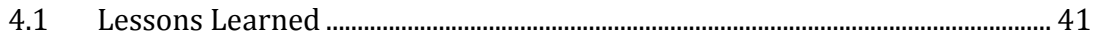

4.2 Recommendations to negotiators ………………………………………………..... 45

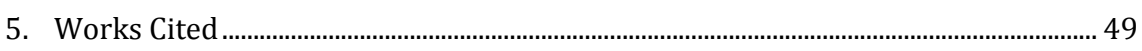

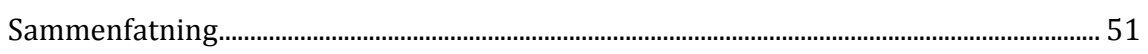

Appendix 1: Detailed Case Studies ...................................................................................................... 57

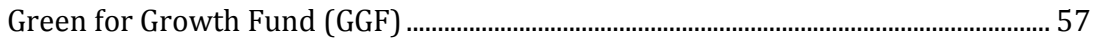

Community Development Carbon Fund (CDCF) ............................................................. 60

GET FiT program in Uganda ....................................................................................................... 64

The Stormwater Management and Road Tunnel (SMART) ........................................... 67

The Ouarzazate project in Morocco ......................................................................................... 70

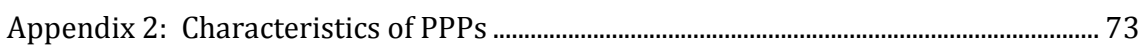

Appendix 3: Overview of selected PPP climate funds.............................................................. 79 



\section{Foreword}

Implementing the Paris climate agreement and the transition to a low carbon economy require adequate finance. Public finance plays a key role - whereas private finance is essential in developing and implementing new and innovative solutions. The Nordic countries are committed to further develop financial instruments and structures that can scale up such investments.

This report discusses the role of the public-private partnerships (PPPs) in scaling-up climate finance and how such partnerships should be designed to best fulfil this task. PPPs provide frameworks to ensure public leadership and accountability in tackling climate change, while enabling the ownership of certain components of climate finance to be transferred to private hands. The report proposes eight recommendations for climate negotiations and effective climate finance, and looks at some good case studies of PPPs worldwide.

Ecofys and University of Cambridge Programme for Sustainability Leadership have carried out the study for NOAK, a working group under the Nordic Council of Ministers. The aim of NOAK is to support the implementation of the new global climate agreement. To this end, the group prepares reports and studies, conducts meetings and organizes conferences assist Nordic and international negotiators in the UN climate negotiations.

Oslo March 2016

Peer Stiansen

Chair of the Nordic Working Group for Global Climate Negotiations 



\section{Introduction}

There are different estimates of the financial resources required to meet the $2{ }^{\circ} \mathrm{C}$ target, ranging from 340 billion to USD 1.1 trillion per year to 2050 (see for example World Bank, 2010; IEA, 2013; SCF, 2014). Whatever the figure, it is clear that there is an urgent need for the accelerated and scaled-up deployment of climate finance. Climate finance is also needed at scale to support adaptation to safeguard the international community from the worse consequences of a changing climate. To provide the required scale of climate finance, the contribution from both public and private finance needs to be significant. Therefore, a strong public commitment is needed to engage with the private sector and ensure climate finance is leveraged and deployed effectively.

Public Private Partnerships (PPPs) are a promising avenue that may offer both practical and conceptual solutions to ensure productive interaction of public and private finance organisations. PPPs aim for public service delivery and, while they seek to benefit from mutually beneficial partnerships, they remain founded on public oversight. They therefore provide frameworks to ensure public leadership and accountability in tackling climate change, while enabling the ownership of certain components of climate finance to be transferred to private hands.

Despite these positive prospects, there has been limited mainstreaming of PPPs in climate finance. This limits how real investment challenges are accounted for and the effectiveness with which risks are tackled to ensure climate investments become viable prospects. Consequently, PPPs for climate finance are often perceived to be too difficult, non-commercial and therefore are not prioritised by the finance community.

PPPs however remain an option and could have an important role in the broader international climate finance landscape. With COP2 $1^{1}$ in sight, and a greater focus on the role of non state actors and public private partnerships to ensure we reach 2 degrees, research and stakeholder consultation is needed to better understand the potential role of PPPs in ensuring effective future deployment of climate support, investments and finance.

${ }^{1}$ The 21st Conference of Parties to the UNFCCC to be held in Paris 2015. 
This report supports negotiators in preparation for COP21. By combining a desk study, one-to-one interviews and a high level dialogue between finance experts and negotiators (at the June UNFCCC session in Bonn), it aims to evaluate the potential role of PPPs in climate finance. More specifically, it addresses the following three key objectives:

1. To contribute to better understanding of the effective means for the public sector to leverage support from the private sector toward climate action;

2. To identify the role and potential of PPPs in climate finance, showcasing examples and case studies; and

3. To apply lessons learnt to support climate negotiations and effective use of PPPs in the future.

In this paper, we first describe the role of PPPs in climate finance (Section 2), then outline the framework conditions needed for PPPs to be successful (Section 3). In Section 4, we give an overview of some case studies and the main points from the stakeholder consultation and in Section 5 draw conclusions and make recommendations. 


\section{Executive Summary}

\section{Problem and research objectives}

There is strong evidence showing the urgent need for scaling-up climate finance to mitigate greenhouse gases in line with the $2{ }^{\circ} \mathrm{C}$ target, and to support adaptation to safeguard the international community from the consequences of a changing climate. While public actors have a responsibility to deploy climate finance, it is clear that the contribution from the private sector needs to be significant. Consequently, a strong public commitment is needed to engage with the private sector and ensure climate finance is leveraged and deployed effectively. In this context, Public Private Partnerships in climate finance are a promising avenue to contribute to climate finance delivery.

This paper builds on a literature review, case studies and stakeholder dialogue to evaluate the potential role of climate finance PPPS, aiming to: contribute to better understanding of the effective means for the public sector to leverage support from the private sector toward climate action; identify the role and potential of PPPs in climate finance, showcase examples and case studies; and apply lessons learnt to support climate negotiations and effective use of PPPs in the future.

\section{The characteristics and promise of PPPS}

PPPs in climate finance can be understood as interaction between public and private financial institutions for the delivery of climate finance. PPPs aim to provide public service delivery and, while they seek to benefit from mutually beneficial partnerships, they remain founded on public oversight. They therefore provide frameworks to ensure public leadership and accountability in tackling climate change, while enabling the ownership of certain components of climate finance to be transferred to private hands.

PPPs are commonly understood to incorporate three key elements: formalised partnership defining the respective roles and responsibilities of public and private actors; risk-sharing among public and private actors; and financial reward for private parties, in line with contractual conditions and risk-sharing arrangements. They can be envisaged as formal partnerships, delineated by specific contractual arrangements between public and private parties. More broadly, they can also inform 
collaboration and cooperation mechanisms between public and private entities, or be understood in relation to the need for public authorities to leverage private finance. They therefore offer both practical and conceptual solutions in climate finance to ensure productive interaction of public and private finance organisations.

\section{Applicability and examples}

PPPs in climate finance have a range of application potential. To date, mitigation has attracted the majority of public-private climate finance, but adaptation is also in scope, provided that challenges such as profitability or risk-management can be overcome. PPPs can be implemented at different scales from individual projects to financial fund level. These represent different stages and scales of climate financing. Fields such as green infrastructure including urban development, natural resource management and innovation appear particularly suited to public-private collaboration. Urban environments also provide interesting contexts for PPPs in climate finance, as they are characterised by the proximity and interaction of public and private stakeholders to deliver public services. Further, PPPs are promising in developing and emerging economics and mechanisms such as Output-Based Aid (a type of result based finance) can support the implementation of pro-poor climate finance PPPs.

A range of examples provide insights into the potential of PPPs in climate finance. However, systematic evaluation of the success of PPPs as a mechanism, particularly in developing countries, is relatively limited. Five case studies are presented in this paper to illustrate their potential:

- The Green for Growth Fund provides an example of a tiered financial mechanism leveraging public and private funds to support energy efficiency and renewable energy projects.

- The Community Development Carbon Fund, is a PPP fund that overcame traditional limitations of carbon markets to support the financing of small-scale, pro-poor projects.

- The GET FiT program, implemented in Uganda, illustrates how PPPs can support in-country risk mitigation and facilitate private investments in renewable energy. 
- Kuala Lumpur's Stormwater Management Road and Tunnel provides an example of a successful infrastructure PPP, serving both mitigation and adaptation.

- The Moroccan Ouarzazate solar project illustrates how PPPs can serve effective renewable energy project development under public leadership.

\section{Framework conditions}

A growing body of literature, PPP examples and dialogue with stakeholder, provides valuable insights into the framework conditions of PPP in climate finance. Three key drivers were identified to implement PPPs: enhanced "value-for-money", through the allocation of different risks to parties most suited to manage them, resulting in reduced costs over project life-cycles; improved implementation and service delivery, benefiting from the specific and complementary characteristics of public and private actors; and increased financial leverage, supported by a range of policy and financial instruments that can be deployed in climate finance PPPs.

Although positive examples have been established, the mainstreaming of PPPs in climate finance remains limited and it is clear that continued efforts are required to remove barriers to their deployment. There are several important barriers to the deployment of PPPs in climate finance including: uncertainty about the implementation of the institutional and financial channels established by climate negotiations, high perceived risks with climate projects, particularly in developing countries, and the limited availability of clearly formulated public policies. Cultural differences between public and private financial institutions are also a concern and, from a private sector point of view, PPPs are often perceived to be complex and to offer limited profitability.

Establishing robust frameworks to support PPPs in climate finance is required to overcome these barriers. Stable legal and regulatory frameworks are needed to allow governments to enter into PPPs and to provide visibility and clarity to private actors. Public leadership in climate finance also calls for clearly articulated objectives and scope for PPPs, so that roles and responsibilities can be clearly delineated. Efficient and transparent public financial management and oversight are lastly needed to support risk mitigation and secure private sector participation.

Other success factors include the willingness for public and private actors to cooperate, which requires improved communication and efforts to implement a co-creation process from early design stages. Finance capacity building efforts, combined with stakeholder engagement 
are further critical to ensuring local buy-in and the participation of local financial intermediaries to find locally-adequate solutions that meet the "on-the-ground" needs of end-beneficiaries.

\section{Recommendations}

Drawing on the research and dialogue, we propose the following eight recommendations for negotiators.

1. PPPs should play a role in climate finance and support both mitigation and adaptation activities. Climate finance needs are considerable and the coordinated efforts of public and private organisations are urgently required. PPPs provide valuable and adaptable conceptual frameworks to support cooperation and collaboration between public and private entities as well as means to increase public leverage of private climate finance if properly designed from the outset.

2. For PPPs to play a role, public authorities should develop enabling frameworks to support climate finance PPPS. PPPs require framework conditions to be in place that provide long-term visibility and stability to investors. These framework conditions should support de-risking of private finance, and, as indicated in our interviews, include PPPspecific legal and regulatory arrangements for example on how costs are recovered as well as transparent institutional responsibilities, clear public financial management, guidelines and oversight processes. The public sector further holds responsibility to identify objectives and formulate narratives that reconcile context-specific needs with both the specific characteristics and opportunities presented by PPPs and a sound investment framework for private finance.

3. Design of a PPP through a process of co-creation and early involvement of private financial institutions should be aimed for. PPPs often face difficulties in implementation stages due to inadequate, unilaterally established processes. Co-creation and early private sector involvement are essential ingredients to ensure transparent and effective financial mechanisms are established, and that PPPs are developed in accordance with the characteristics and needs of all actors involved.

4. Mobility programs of staff between public and private financial institutions can be used to improve mutual understanding and communication. Communication difficulties are apparent that fragment the climate finance landscape and limit the scope of collaboration between public and private actors. Common interests, financial viability and societal imperatives require improved mutual understanding of the 
characteristics, needs and priorities of climate finance participants. Mobility programs whereby staff are exchanged for a period between different organisations may be an effective way to build bridges and reconcile the languages and understandings of public and private actors.

5. Public financial institutions could support risk-taking initiatives to enlarge the scope of bankable projects. Many potential fields of application of climate finance are characterised by high perceived risk and low levels of experience. Public financial institutions are best placed to overcome this barrier and the provision of first loss catalytic capital has a strong impact on leveraging private finance. Increased joint risktaking, supported by expert technical assistance, will support scaledup and accelerated deployment of climate finance.

6. Developed countries should support the emergence of PPPs in developing countries. Context-specificity is pivotal to the success of PPPs. The participation of local public and private stakeholders and financial institutions in the design and implementation process is needed to ensure adequacy to on-the-ground socio-economic and cultural realities and to support capacity building efforts.

7. Robust stakeholder consultation processes should be established and implemented. PPPs in climate finance are intimately tied to environmental, social and economic sustainability. This societal complexity, combined with their inherent requirements, warrants careful consultation of public, private as well as civil society stakeholders. In particular, the context-specific requirements of climate finance calls for interaction with local financial institutions and intermediaries. Further, PPPs aim to deliver public services and end-beneficiaries should be duly considered to ensure that climate finance PPPs address "on-the-ground" needs effectively.

8. Systematic evaluation of implemented climate finance PPPs should be encouraged. The case studies identified in this study illustrate how certain objectives can be met by PPPs in climate finance. However, there is a lack of rigorous evidence, particularly in developing countries, as to whether they are the most effective way to deliver those objectives. More systematic evaluation of real examples of PPPs would contribute to greater interest in their use and also help identify more specific success factors. 



\section{Public-Private Partnerships for Climate Finance}

\subsection{Climate finance}

Addressing climate mitigation and adaptation globally requires the participation of a large range of actors and considerable financial resources. The UNFCCC formalised a collective goal for developed countries of mobilising USD 100 billion per year by 2020 for climate action in developing countries.

Available definitions (see for example SCF, 2014, p. 5, CPI, 2014, p. 8) highlight the broad scope of climate finance, relevant to both mitigation and adaptation activities, and including public as well as private finance. CPI's definition further includes the terminology "public framework expenditure", which stresses the public sector's role in establishing framework conditions favourable to mobilising private finance, which is of particular relevance to this study. A group of 19 bilateral climate finance provider countries have developed a common methodology for tracking and reporting towards the USD 100 billion a year goal (TWG, 2015 as cited in OECD/CPI 2015).

Many investments or financial pledges have been made by public and private actors. OECD and CPI (OECD/CPI 2015) estimate that the aggregated volume of public and private climate finance mobilised by developed countries for developing countries reached USD 61.8 billion in 2014. Multilateral development banks accounted for a substantial increase in the finance flows.

In its latest assessment of the global climate finance landscape, OECD/CPI finds that the majority $(77 \%)$ of climate finance goes towards mitigation, with $16 \%$ on adaptation and test on activities to target both. Mobilised private climate finance is predominantly going to mitigation activities.

Climate finance involves a wide range of actors, from financial institutions or institutional investors, to financial intermediaries to endbeneficiaries. In 2014, private actors accounted for climate finance of 16.7 billion, and public actors for the remaining USD 45 billion (OECD/CPI, 2015). The report acknowledges that it is difficult at this 
stage to be complete in the data about private sector finance or draw general conclusions about the mobilisation of private finance through public finance.

PPPs have the potential to contribute to closing the financing gap but will need to be implemented in developing countries as well as developed countries. In light of the sheer size of the climate change challenge though, it is clear that they can only be a part of the solution to mobilise public and private finance.

\subsection{Public-private partnerships}

In this section, we outline the essential components of PPPs and examine fields and scale of climate finance where they might be applied.

\subsubsection{Formal definition and broader applicability}

Public Private Partnerships (PPPs) refer to a range of possible relationships between public and private actors for the delivery of a common goal. They are commonly understood to incorporate three key elements (a description of other common characteristics of PPPs can be found in Appen$\operatorname{dix} 2$ ):

- Formalised partnership defining the respective roles and responsibilities of public and private actors. There is a spectrum of possible contractual arrangements between public and private entities. These range from relatively short term service contracts to long-term joint venture arrangements (see Appendix 2).

- Risk-sharing among public and private actors. PPPs offer a range of risk-sharing mechanisms. They recognise the differing characteristics of public and private actors, and seek to optimise the effectiveness of public service delivery by allocating risks to parties most suited to address them.

- Financial reward for private parties, in line with contractual conditions and risk-sharing arrangements.

These elements are captured in the following definition provided by the World Bank: "A long-term contract between a private party and a government agency, for providing a public asset or service, in which the private party bears significant risk and management responsibility" (World Bank, 2012, p. 11). 
In a broader context, PPPs can be considered as part of the range of policy and financial instruments available to public authorities to "catalyse" or "leverage" private finance. The formal characteristics of PPPs are further valuable to inform effective collaboration between public and private actors.

\subsubsection{Fields of application}

To date "public-private recipients were almost exclusively active within the mitigation sector" (CPI, 2015). The business case for adaptation activities is currently not seen as robust except in those sectors directly impacted by climate change such as the food or water sectors. To date therefore the most active private finance for adapation is in the insurance sector that is starting to evaluate the risk of non-resiliance. Therefore, the public sector must formulate a clear narrative around adaptation finance that makes business sense so that the private sector can engage and help fill the gap.

The potential field of application of PPPs in climate finance remains very broad. In a recent report by Green Growth Best Practice (GGBP, 2014), three main thematic areas were identified for publicprivate collaboration:

- Green infrastructure, where they hold the potential for enhancing the efficiency of large infrastructure investments, mobilising the resources needed to support infrastructure projects of a smaller scale, and supporting innovation as well as the emergence of new growth areas.

- Natural resource management, where the importance of shared public and private ownership of natural resources to ensure shared valuation and awareness can help achieve effective compliance and enforcement.

- Innovation, where public-private collaboration can result in longterm certainty for private sector innovation investments, stimulate "green" entrepreneurship and help establish networks that support innovative outcomes.

Urban environments provide interesting context for the design, testing and implementation of PPPs, for example with regard to infrastructure development. They are characterised by the proximity and interaction of public and private stakeholders to deliver highly context-specific services. Interaction with the general public/end-consumers also awards 
urban environments the possibility to develop PPPs with an extra dimension (as illustrated in Box 2).

Additionally, the application of PPPs in developing and emerging economics brings forward examples of successful sustainable and propoor PPPs generating environmental and social benefits. This further demonstrates the potential of PPPs to serve as a vehicle for simultaneously addressing climate change and development concerns and catalysing green growth across different sectors of the economy.

On the ground experience has shown that PPPs that deliver projects or services to help tackle poverty (pro-poor) can be effective. They require specific economic and sustainability considerations though as engaging the private sector for these services can be challenging due to relatively high delivery costs and difficulties in achieving profitable business models (ADB, 2008). Recently, so-called Output-Based Aid (OBA) frameworks have been developed to enable PPPs to effectively deliver pro-poor services. In addition, performance-based subsidies complement user-fees and enable public authorities and donors to engage in partnerships with private third-parties that would otherwise be unable to operate profitably.

The following text boxes, present some examples of climate change, sustainability and pro-poor PPPs in different areas of application, from the development of clean and efficient public transport infrastructures, to sustainable water and forestry management, to reduction of $\mathrm{CO}_{2}$ emissions through efficient lighting technologies.

\section{Box 1: The Mexico City Metrobus Project²}

Mexico City's measures to improve air quality have been diverse, from closing the city's most polluting factories to banning cars in the city's metropolitan area one day per week. Against this background the Metrobus project (a Bus Rapid Transportation system) was launched as part of the Programme to Improve Air Quality in the Mexico City Metropolitan Area (MCMA) 2002-2010 (PROAIRE). The established PPP model is based on a concessionaire and comprises of several stakeholders: the first is Metrobus, a decentralised body of Mexico City's government which plans, controls and manages services. The second is the service operators, and the third group involved fare collectors, which includes INBURSA as the bank, and two other companies that install, operate and maintain the fee collecting system. Finally, a trust fund was created to gather all collected fees so to pay out the corresponding amounts to the transportation companies based on the number of

2 http://www.siemens.com/press/pool/de/events/2014/infrastructure-cities/2014-06-CCLA/mexicoclimate-close-up.pdf; http://www.oecd.org/env/cc/Case\%20study\%20Mexico.pdf 
kilometres travelled. Metrobús has resulted in 30\% fewer accidents, $40 \%$ lower travel times, and a $15 \%$ modal shift from cars to public transit. Furthermore, during its first six years of operation, the first BRT line was able to reduce $\mathrm{CO}_{2}$ emissions by 300,000 tons. Now, each year the Metrobús is estimated to reduce $\mathrm{CO}_{2}$ emissions by 110,000 tons; nitrogen oxide by 690 tons; particulate matter by 2.8 tons; and hydrocarbons by 144 tons.

\section{Box 2: The Ghana Clean Water Project ${ }^{3}$}

Ghana faces major problems concerning drinking water provision and wastewater management. These problems are exacerbated by the ongoing expansion of irrigated areas and advancing industrialisation. An example is the Ghana Nuts (GNL), a large food company, which produces edible oils. The production process results in 60,000 litres of wastewater every day, while in the immediate vicinity of the plant drinking water is in short supply. A PPP between the German company AWAS International GmbH and the Deutsche Investitions- und Entwicklungsgesellschaft $\mathrm{mbH}$ (DEG) (working on behalf of BMZ) was established to tackle these environmental and social problems. AWAS covered half of the overall costs of the project, while DEG contributed to the remaining amount to a maximum of EUR 200,000. AWAS built a water treatment facility, which cleans virtually all GNL's wastewater for reuse in the production process. The PPP was planned to last up to three years to ensure that the facility will continue to be used, AWAS also provided local GNL employees with training on how to operate and maintain the plant, and organised information events for local industries and inhabitants. Finally, the company installed a public drinking water well to supply drinking water to the local hospital and those living nearby. For AWAS the project was an opportunity to gather invaluable market experience on the African continent.

\section{Box 3: The Chesapeake Forest Project}

The Chesapeake Bay is a major area of both recreational and commercial fishing for the State of Maryland (United States). The environmental quality of the Bay has been seriously threatened by wastewater discharges and minimal controls of agricultural runoff. Both state and local governments lack the financial and personnel capability to address those concerns. It was in this situation that the Chesapeake Forest public-private Partnership (CFP) was created, comprising the State of Maryland Department of Natural

3 http://www.developpp.de/en/content/clean-water-\%E2\%80\%93-commodity-short-supply;

http://responsive-pr.de/wordpress/wp-content/uploads/develoPPP-report-32-Ressourceneffizienz_DE.pdf 
Resources (DNR); a major philanthropic foundation; a non-profit public interest group; and a for-profit consulting forestry firm. For the initial land acquisition that ultimately led to the partnership, the State of Maryland provided USD 16.5 million for half of the total 58,000 acres; the non-profit public interest group, acting on behalf of the philanthropic foundation, purchased the remaining 29,000 acres for USD 16.5 million. The initial phase covered only the 29,000 acres which terms for the use of land including a detailed Sustainable Forest Management Plan, (to be implemented over a 3 years) identifying areas in the forest, where wood products could be harvested without negative environmental and consequently social impacts, as well as an environmentally sustainable level of harvesting. The private partner managed the harvesting operations, the revenues from which pay for the contract, and provide additional funds to both the State and local governments. Based upon the success of the PPP for the management of the initial 29,000 acres, the terms of the final PPP contract cover the entire surface.

\section{Box 4: The en.lighten Initiative 4}

In 2009, the UNEP Global Environment Facility (GEF) established the "en.lighten initiative" to accelerate transition towards environmentally sustainable, energy efficient lighting technologies, as well as to develop strategies to phase-out inefficient incandescent lamps. The initiative has been set up as a PPP between the UNEP, OSRAM, and Philips Lighting company, and serves as a platform to build synergies among international stakeholders, identify global best practices, share knowledge, and encourage countries to develop integrated efficient lighting strategies. Key elements of en.lighten are an international forum of energy efficient lighting experts and a Centre of Excellence, focusing on lighting policies, and consumers and environmental protection. Additionally, the established PPP supports interested countries in designing and implementing National Efficient Lighting Strategies through its Global Efficient Lighting Partnership Programme. The initiative has already produced Country Lighting Assessments for 150 countries. UNEP estimates that the replacement of all inefficient on-grid and off-grid lighting in the world would result in over 1,000 terawatt hours (TWh) of electricity savings annually, equivalent to the annual electricity use of India and the United Kingdom combined. This would yield annual cost savings of over USD 140 billion and would also achieve annual $\mathrm{CO}_{2}$ reductions of 580 million tonnes. ${ }^{5} 66$ developing and emerging countries have joined this partnership Programme and committed to energy efficient lighting by 2016. It has been estimated that the 66 en.lighten partner countries alone will save over USD 7.5 billion and 35 million tonnes of $\mathrm{CO}_{2}$ annually.

${ }^{4}$ http://www.unep.org/energy/Projects/Project/tabid/131381/language/en-US/ Default.aspx?p=b86b5b4e-86a4-4e99-ae57-8c936373785c 
The cases presented above provide insights into the diversified application of PPPs and their potential. They further illustrate how PPPs can support climate finance, whether the partnerhip strictly focuses on the delivery of finance or whether finance forms a part of a broader partnership.

These examples also highlight that the scale of application varies across partnerships. PPPs can indeed be implemented at different stages and at different scales of climate financing: at an end-use or project level to tackle specific mitigation challenges or address needs in specific contexts; and on the funding side or at a more programmatic-level.

A growing number of climate funds indeed mobilize public-private finance on a structural level looking for effective means of disbursing those funding and simultaneously benefit both actors (see Appendix 3 for examples). 



\section{Framework conditions}

\subsection{Drivers}

PPPs aim for public service delivery and, while they seek to benefit from mutually beneficial partnerships, they are founded on public oversight. They therefore respond to different drivers to provide frameworks to ensure public leadership and accountability in tackling climate change, while enabling the ownership of certain components of climate finance to be transferred to private hands.

\subsection{1 "Value-for-money"}

Value for money is an important driver for both public and private parties. This can be achieved by allocating risk management in PPPs to the party that offers the best value for money. Optimal use of resources over the entire project life-cycle ultimately optimises the process and results in long-term value for money. To this end, private sector engagement has the potential to give access to new sources of revenue and/or to find innovative ways of creating value for money.

\subsubsection{Efficiency in implementation and service delivery}

Efficiency in implementation is also important for public service delivery, linked strongly to value for money. Partnership with private actors can introduce elements of performance benchmarking to complement traditional public sector modes of delivery, placing additional attention on efficiency considerations, resulting in enhanced public sector management. The allocation of risk to the private sector ensures strong links between service delivery and returns, and offers an incentive to improve efficiency and quality. Ultimately, enhanced management and performance incentives can result in accelerated and/or improved service delivery. 


\subsubsection{Financial leverage}

As mentioned earlier, climate finance needs are much higher than could be provided by the public sector alone. PPPs offer the opportunity to leverage additional resources for the delivery of public services. As an example, PPPs can be used to engage the private sector in otherwise unattractive markets as well as to trigger the developments of new markets. This requires that public authorities implement stable policy environments and adequate financial instruments, to enable PPPs and related private sector capabilities to develop. PPPs can also be implemented in existing and mature markets encourage private sector investments. PPPs can therefore be used to initiate and guide the mobilisation of private finance in a direction desirable to addressing climate change. The following text box provides the example of energy efficiency (EE), where PPPs can result in the leveraging of commercial financing.

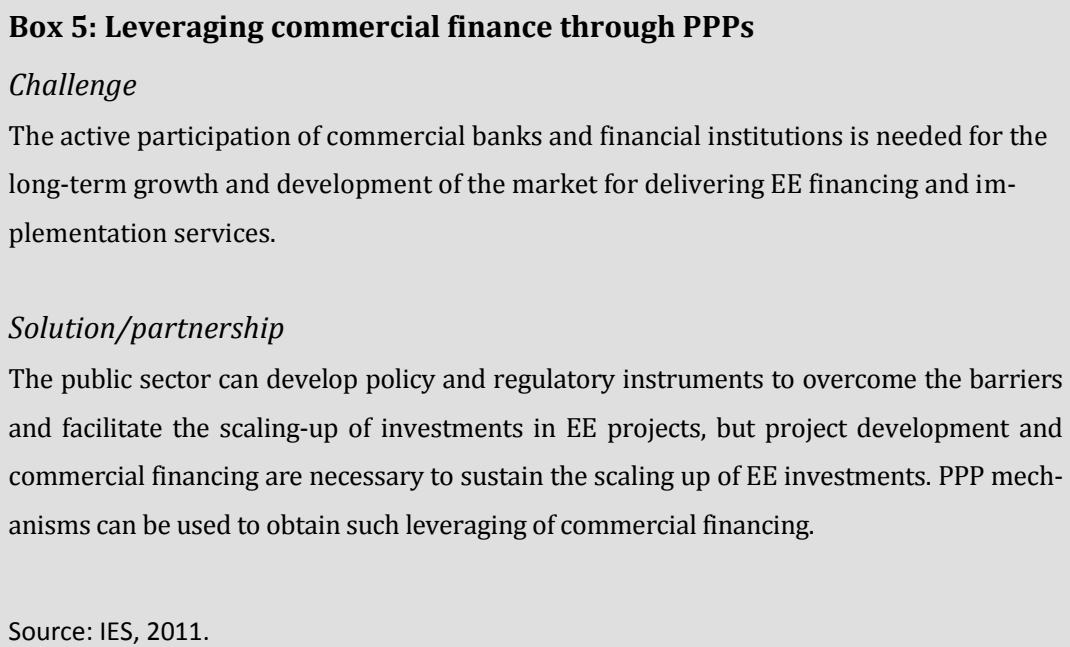




\subsection{Enabling Environment}

Public authorities hold an important responsibility to establish frameworks suitable for PPPs to deliver climate finance services. PPPs require policy and market conditions that embrace both public and private interests. These interests depend on country contexts, legal and regulatory conditions, existing service delivery infrastructures as well as on the maturity of financial markets. Box 8 below, presents an overview of central components of PPP frameworks.

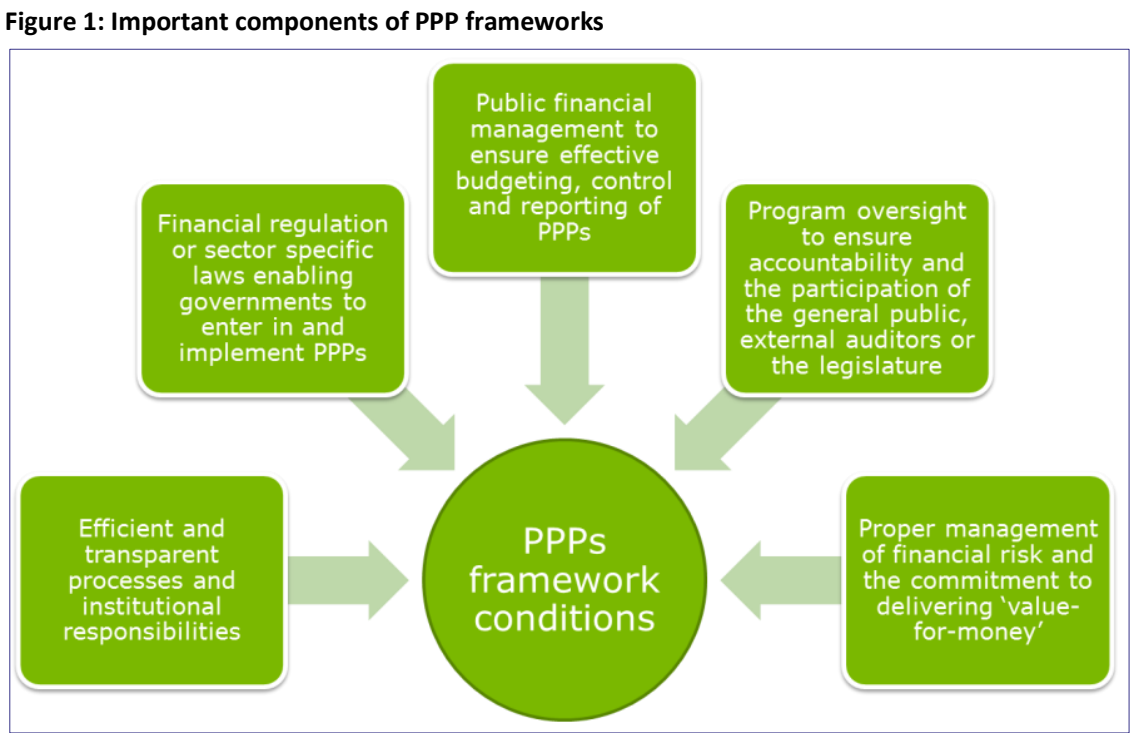

Source: Adapted after World Bank, 2012.

\subsection{Risks and barriers}

Risks in PPPs influence the supply and demand of finance. They translate into a variety of barriers to the deployment of PPPs particularly in climate finance as climate action in some areas of mitigation may rely on immature technologies, industries and regulatory structures. Moreover, there is a lack of information and awareness on many climate abating technologies, coupled with limited experience and proven outcomes.

The following table provides an overview of the World Bank's typology of risks for climate change as well as some examples and notes on the relevance to PPPs in climate finance. 
Table 1: Overview of risks in climate change action and relevance to PPPs in climate finance

\begin{tabular}{|c|c|c|}
\hline Risk category & Description and examples & Implications for PPPs in climate finance \\
\hline $\begin{array}{l}\text { Political, policy, } \\
\text { social }\end{array}$ & $\begin{array}{l}\text { - Political, policy and social risks are social in } \\
\text { nature and originate from governments and } \\
\text { individuals. } \\
\text { Examples: public governance, legal and own- } \\
\text { ership rights, permitting, policy uncertainty, } \\
\text { regulatory changes, public perception, security } \\
\text { risk. }\end{array}$ & $\begin{array}{l}\text { Instable political/policy environments are } \\
\text { powerful deterrents for private investors } \\
\text { that need long-term visibility. Public } \\
\text { authorities must lead the mitigation of } \\
\text { such risks. }\end{array}$ \\
\hline $\begin{array}{l}\text { Technical, physi- } \\
\text { cal }\end{array}$ & $\begin{array}{l}\text { - Technical and physical risks are associated to } \\
\text { the physical environment of projects and are } \\
\text { either technology specific or relate to unex- } \\
\text { pected catastrophic events. } \\
\text { Examples: construction risks, disasters, relia- } \\
\text { bility of outputs, environmental impacts. }\end{array}$ & $\begin{array}{l}\text { PPPs can combine innovative approaches } \\
\text { and public guarantees and present op- } \\
\text { portunities to overcome technical risk. }\end{array}$ \\
\hline $\begin{array}{l}\text { Commercial, } \\
\text { market }\end{array}$ & $\begin{array}{l}\text { - Commercial and market risks are economic } \\
\text { in nature and are linked to the value of inputs } \\
\text { and outputs or to the cost and availability of } \\
\text { financial resources. } \\
\text { Examples: currency fluctuation, input/output } \\
\text { price volatility access to capital, credit default, } \\
\text { residual value risk. }\end{array}$ & $\begin{array}{l}\text { Private sector participations can only be } \\
\text { expected when market conditions are } \\
\text { favourable. High commercial or market } \\
\text { risk means PPPs are unlikely to succeed. } \\
\text { The private sector offers highly valuable } \\
\text { experience to mitigate such risks. }\end{array}$ \\
\hline Outcome & $\begin{array}{l}\text { - Outcome risks refer to the ability of climate } \\
\text { projects to meet objectives (e.g.: carbon } \\
\text { emission reductions) within expected costs. } \\
\text { Examples: emission reduction targets, co- } \\
\text { impacts, financial sustainability. }\end{array}$ & $\begin{array}{l}\text { Leveraging public experience with service } \\
\text { delivery and private efficiency holds } \\
\text { some promise in tackling outcome risks. }\end{array}$ \\
\hline
\end{tabular}

Source: Adapted from WB, 2014 and CPI, 2013.

National barriers include limited availability of clearly formulated public policies as outlined above, lack of knowledge about priority market sectors, as well as international uncertainty on the institutional and financial structures and channels deriving from ongoing climate negotiations. Additionally, in developing countries, risks and barriers include legal and regulatory frameworks and market uncertainty.

Perceived risks in PPPs are often high because of the involvement of both private and public sector actors. Public sector actors may perceive that the private sector is not delivering value for money because pricing reflects this high risk perception. Additionally, private investors can bedeterred from engaging in PPPs. Overcoming these barriers requires the availability of a range of policy, technical and financial expertise to formulate effective risk-sharing. This expertise is often not readily available to both public and private actors, particularly in developing countries. The following text boxes provide insights into specific barriers and risks from a type of investor and project example. 


\section{Box 6: Barriers to Private Equity/Venture Capital}

Slow fund manager formation

- Long fund-raising periods deter potential management teams

- Potential management teams lack capital

\section{Slow capital raising}

- Fund managers lack track records

- New investment areas lack a history of returns

- New investment areas are perceived to be risky

\section{Limitations to capital deployment}

- Pioneering market has high costs

- Difficulties in capturing all the returns from pioneering investments

- The benefits of carbon abatement are not easily monetised

Source: IFC, 2011.

\section{Box 7: Bangkok's Skytrain (BTS) ${ }^{6}$}

In the 1990s Bangkok's heavy traffic volume was making the city one of the worst in terms of congestion and air pollution. The government decided to develop a PPP model based on a 30-year Build-Operate-Transfer (BOT) scheme for an elevated rail transit system. The public partner was the Bangkok Metropolitan Administration (BMA), while on the private side the Bangkok Transit System Corporation (BTSC) was formed. The total cost of the BTS was estimated at THB 55.5 billion (USD 1.4 billion), with financing coming from equity and debt funding. Debt came from two development banks - the $\mathrm{IFC}^{7}$ and the $\mathrm{KfW}^{8}$ as well as from Thai banks. The SkyTrain system entered into service in 1999. Under the terms of the concession contract, BTSC was permitted to retain all revenue deriving from the system operation, though BMA's approval was required before adjusting system fares. An implementation problem emerged as the riders forecast, predicted 600,000 riders per day for the opening of the system, while only 380,000 riders per day was reached by 2006. This inaccuracy led to several major financial problems and the near collapse of the private company BTSC. Although the BTS project can be considered

${ }^{6} \mathrm{http}: / /$ www.unescap.org/sites/default/files/Case\%201\%20-\%20Traffic\%20Demand\%20-\%20Bangkok\% 20BTS_0.pdf

${ }^{7}$ International Finance Corporation.

${ }^{8}$ Kreditanstalt für Wiederaufbau. 
successful from an operational point of view - as it has contributed to ease traffic congestion in the city - it has proved to be very unsuccessful for the investors and the financiers, possibly leading to investors' averseness towards similar risk investments in the future (i.e. to rely on fares collection).

\subsection{Success factors}

The success of PPPs depends on a large range of factors, and contextspecific aspects such as field of application and geographical coverage, should be duly considered. The following table provides some insights into success factors and lessons learnt in green infrastructure, natural resource management and innovation.

Table 2: Success factors in climate change action and relevance to PPPs in climate finance

\begin{tabular}{|c|c|c|c|}
\hline & Innovation & Natural resources & Green infrastructure \\
\hline 1 & $\begin{array}{l}\text { Prioritising public resources at } \\
\text { early stages and private re- } \\
\text { sources in later stages. }\end{array}$ & $\begin{array}{l}\text { Early collaboration in resource man- } \\
\text { agement and planning to support } \\
\text { strong buy-in and compliance. }\end{array}$ & $\begin{array}{l}\text { Replicating successful PPP } \\
\text { approaches from areas such } \\
\text { as energy, water or transport. }\end{array}$ \\
\hline 2 & $\begin{array}{l}\text { Ensuring long-term and stable } \\
\text { financial support, regulations and } \\
\text { price signals are in place. }\end{array}$ & $\begin{array}{l}\text { Carrying out resource valuation to } \\
\text { ensure strong support and enable } \\
\text { viable enforcement regimes. }\end{array}$ & $\begin{array}{l}\text { Overcoming financing and } \\
\text { other weakest link issues to } \\
\text { ensure smaller scale infra- } \\
\text { structure development. }\end{array}$ \\
\hline 3 & $\begin{array}{l}\text { Supporting "green" entrepre- } \\
\text { neurs with capacity building. }\end{array}$ & $\begin{array}{l}\text { Building awareness of natural re- } \\
\text { source constraints and the benefits } \\
\text { of wise resource management. }\end{array}$ & Support new growth areas. \\
\hline 4 & $\begin{array}{l}\text { Ensuring public authorities act to } \\
\text { facilitate and connect research } \\
\text { institutions. }\end{array}$ & & \\
\hline
\end{tabular}

Source: Adapted from WB, 2014 and CPI, 2013.

The success of PPPs depend on a shared willingness to cooperate from all parties involved and the development of a shared vision with transparent and clearly articulated goals is essential. Private actors can help keep goals realistic and achievable whereas public authorities remain "at the helm" of public service delivery. 
Adequate legal and regulatory provisions specifically targeting PPPs, complemented by precise PPP policies have to be established. Simplified policy frameworks and transparent governance systems will support the streamlining of PPPs. However, PPPs can at times be too demanding and public authorities should always remain critical in their assessment of the costs and benefits.

Multiple stakeholder are involved in the processes of partnerships. Clear definition and assignment of roles and responsibilities is essential. Effective and open communication helps increase transparency and accountability, and support the establishment of trusted relationships between parties.

Capacity building at an early stage can enable partnerships through policy instruments. Mobilising, allocating and using climate finance is indeed complex and finding adequate mechanisms will require deep understanding of the parties involved, of the geographic context, of the technologies used and of the field of action. Technical issues include timing of implementation, the relevance of debt and equity mechanisms, the implications of commercial vs. below-market financing, the structuring of payments to meet up-front capital requirements or the use of aid mechanisms such as Output-Based Aid.

Thorough stakeholder engagement is lastly necessary at all stages of PPPs. Aside from the parties involved in the partnership itself, stakeholder engagement is needed to ensure appropriate oversight as well as to support the adoption of PPP models by the general public and/or endconsumers. Streamlined institutional structures, capacity building and effective communication as well as awareness modalities are crucial to enabling this.

\subsection{Paris and beyond: Prospects for the future?}

A new climate agreement at COP21, in November/December 2015 in Paris, is a key feature on the climate change agenda. An agreement has the potential to impact the climate landscape by providing significant signals to international and national authorities as well as to private investors on the need to shift to low-carbon economies. 
A new agreement is likely to affect the mobilisation and deployment of climate finance (OECD-IEA, 2014), Below is an overview of selected institutions/initiatives that most likely will be affected:

- International institutional arrangements: are key to the thematic and geographic balance in the mobilisation and allocation of climate finance. A climate agreement could improve organisational effecttiveness, coordination and co-operation between climate finance institutions, streamline climate finance allocation processes, and enable better synergies between institutional arrangement inside and outside of the UNFCCC.

- In-country enabling environments: are pivotal to effective mobilisation and use of climate finance. The OECD-IEA report differentiates between pull factors (in-country regulations helping to attract investments and help implementation) and push factors (policies, regulations and instruments contributing to help mobilise climate finance and investments for use in recipient countries). On the pull side, an agreement at COP21 could encourage Parties to establish "predictable, transparent and responsive" enabling environments and urge them to price GHGs coherently and sustainably, in line with their social costs. An agreement could further support better co-ordination on national institutional frameworks and collaboration on environmental and social standards. Lastly, Parties would be encouraged to develop clear timelines for the period to 2020. On the push side, an agreement could stress the need to tackle the fragmentation of international climate finance, and encourage inter-agency co-ordination within and between countries.

- Financial instruments and tools: are available for use depending on the target countries, technologies and project types. Enhanced use of innovative mechanisms is key to effective mobilisation and deployment of climate finance and COP21 may contribute in explicitly encouraging the use of a diversified and innovative range of mechanisms and instruments as well as providing support for effective exchange of information.

- Transparency in climate finance tracking: is important for trust building among stakeholders as well as to support the evaluation of climate finance and the identification of promising scale-up options. Effective tools on monitoring, reporting and verification (MRV) in terms of consolidating the balance between costs and benefits could be an important outcome of a new agreement. 
In light of the above considerations, PPPs offer opportunities to support climate finance actions as effective and transparent relationships between public and private parties may be helpful in ensuring coordination and co-operation. PPPs can be established on an international program level and on in-country project levels, and could contribute to strengthening both international and national operating environments. The interaction of public and private stakeholders also offers potential to broaden the diversity of financial and policy mechanisms used and to ensure public and private finance are optimally leveraged. Lastly, the monitoring and oversight needs of PPPs may provide insights on effective cost and benefit balancing. 



\section{Case studies and stakeholder dialogue}

\subsection{Case studies}

The traditional way of procuring public services and infrastructures though fiscal budgets is increasingly becoming unviable particularly in developing economies. Consequently, governments across the world are exploring the use of PPPs to deliver infrastructure and other services and are looking to leverage private finance. The rationale for their use is two-fold: the need to buffer public finance with private sector investments, combined with the possibility to enhance innovation and efficiencies in service provision.

Below an overview of selected case studies is presented. These case studies provide insights into the potential application of PPPs in climate finance in different fields, at project or program level, for mitigation and adaptation as well as in specifically addressing climate finance or in supporting effective risk mitigation or financing of projects with climate action components. However, systematic evaluation of the success of PPPs as a mechanism, particularly in developing countries, is relatively limited. The literature tends to describe success in terms of programme outcomes but not whether, or what aspects of the PPP, contribute to efficiency of delivery. Similar observations on the lack of evaluation were made in [IOB 2013].

The case studies more specifically:

- The Green for Growth Fund provides an example of a tiered financial mechanism leveraging public and private funds to support energy efficiency and renewable energy projects.

- The Community Development Carbon Fund, is a PPP fund that overcame traditional limitations of carbon markets to support the financing of small-scale, pro-poor projects.

- The GET FiT program, implemented in Uganda, illustrates how PPPs can support in-country risk mitigation and facilitate private investments in renewable energy. 
- Kuala Lumpur's Stormwater Management Road and Tunnel provides an example of a successful infrastructure PPP, serving both mitigation and adaptation.

- The Moroccan Ouarzazate solar project illustrates how PPPs can serve effective renewable energy project development under public leadership.

More in-depth insights into these are presented in Appendix 3. Furthermore, we elaborate further on key learnings in Section 5 of this report.

\subsubsection{Green for Growth Fund (GGF)}

The GGF, operating in Southeast Europe, is a public-private partnership aiming to achieve a $20 \%$ reduction in energy consumption and/or a $20 \%$ reduction in $\mathrm{CO}_{2}$ emissions in target countries by 2020 , in line with the Europe-2020 initiative. The fund aims to bridge knowledge gaps and act as a local market enabler. It provides direct financing loans to non-financial institutions, as well as refinancing of partner financial institutions by establishing credit lines for on-lending. GGF's organizational structure comprises of international donors and financial institutions and private investors. The involvement of these parties enables a tiered risk-sharing structure which allows for low-risk financing for private investors investing commercial capital. Since its inception, GGF has financed nearly 10,000 investments in EE and RE measures that have enabled overall savings over $671,000 \mathrm{MWh}$ of energy and reduction in $\mathrm{CO}_{2}$ emissions by 176,000 tons on an annual basis in targeted countries. The most common types of measures financed are energy-efficient process-related equipment for businesses and improvements to buildings for households and businesses.

\subsubsection{Community Development Carbon Fund (CDCF)}

The CDCF was established in 2003, as a public-private partnership comprising of 9 governments and 16 private firms, administered by the World Bank, with a total capitalization fund of USD 128.6 million. It aims to create a suitable financial environment for small communities, by providing carbon finance to small-scale projects simultaneously benefitting local communities and abating greenhouse gas emissions in the least developed countries (LDCs) and poor areas in all developing countries. As of October 2013, the CDCF portfolio comprises of 22 ac- 
tive CDM projects, of which 13 provide indirect community benefits (e.g. proved working conditions and livelihoods of waste pickers) and 9 generate direct community benefits (e.g. cheaper, safer and more reliable energy). The CDCF reported a fund capitalization of USD 118 million, with average projects size of 255,000 carbon credits $\left(\mathrm{tCO}_{2} \mathrm{e}\right)$. The total CDCF's project portfolio was equal to $5,600,000$ carbon credits $\left(\mathrm{tCO}_{2} \mathrm{e}\right)$. An example of a project supported by the CDCF is a highly successful Solar Home System initiative in Bangladesh in which international donors, a government entity, local partner organisations an suppliers collaborate to provide financial mechanisms that are accessible to end-beneficiaries, and include output-based guarantees.

\subsubsection{GET FiT Program in Uganda}

In 2010 the United Nations Secretary General's Advisory Group and Climate Change (AGECC) approached the Deutsche Bank Climate Change Advisors (DBCCA) to develop innovative concepts to drive renewable energy investments in developing regions. DBCCA responded by creating the Global Energy Transfer Feed-in Tariffs Program (GET FiT), an international PPP aiming to assist East African nations in pursuing a climate resilient low-carbon development paths. The GET FiT rationale builds upon the concept that governments in the developed world and/or multilateral organisations can support the upgrading of existing regulatory frameworks in emerging economies to improve the risk profile and commercial viability of renewable energy from a private investor's point of view. Roll-out of the Uganda Program was launched in May 2013 in Kampala. The program was designed to simultaneously leverage private investment in renewable energy generation projects, and target barriers for investors looking at investments in small renewable energy projects (1-20 MW). It aims to fast-track a portfolio of about 20-25 small-scale renewable energy (RE) generation projects, with a total installed capacity of up to $170 \mathrm{MW}$. The main financial feature of the Program is a front-loaded results-based premium payment.

\subsubsection{The Stormwater Management Road and Tunnel}

Since the early 1980s Kuala Lumpur has witnessed rapid population and related urbanization growth which have resulted in a marked increase in flash flooding in the central areas of the city. In 2001 the Malaysian government responded by launching a call for proposals resulting in the innovative idea of the mixed-used tunnel, diverting and stor- 
ing the storm water, and allowing traffic flow when empty of water. To implement the project a PPP was established between the Malaysian government and two private companies, and implemented through a concession contract of 40 years. The total cost of the SMART project was USD 510 million. The private sector provided a third of the total funds, with the Malaysian government expending USD 340 million and the private companies covering the remaining USD 170 million. In order to recoup the capital investment and operating expenses, the concessionaire charges a toll fee for private cars and light vans for each use of the tunnel. In addition to the effective management of flooding situations, which offers potential in terms of climate adaptation, the tunnel has helped reduce congestion and cut down on travel time into the city centre between 10-15 minutes, which results in reduced emissions.

\subsubsection{The Maroccan Ouarzazate Project}

To meet the fast growing demand for electricity, Morocco will need to double its power generation capacity by 2020 . This substantial challenge is compounded by Morocco's high reliance on energy imports that currently account for $97 \%$ of total supply. The government reacted to these challenges by launching the Morocco Solar Plan in 2009. The USD 9 billion plan calls for the development of 2,000 MW by 2020, starting with the $500 \mathrm{MW}$ Ouarzazate project, implemented through a PPP model enabling to tap private-sector capital, technical expertise, and managerial efficiency. The partnership incorporates Power Purchase Agreements (PPAs), and sets the terms for a large amount of concessional finance provided by the Government of Morocco and International Finance Institutions (IFIs), covering the expected 25-year lifetime of the project. The PPP is based on a Special Purpose Vehicle, a consortium of private developers and the Moroccan Agency for Solar Energy (MASEN). It has been foreseen that the plant would have a capacity of between 125 and $160 \mathrm{MW}$ and would use the most mature CSP technology currently available, with three hours of molten salt thermal energy storage capacity. Although, the final estimates on the technical performance of the plant have not been disclosed yet, it is expected that the final bid results will be consistent with an expected annual power generation between 420 and $430 \mathrm{GWh}$. 


\subsection{Insights from stakeholders}

Ecofys and CISL carried out interviews with leading experts from public, private and financial organisations. PPPs in climate finance are indeed subject to different views, which must be duly accounted for if they are to be deployed effectively.

Firstly, it was that noted that PPPs are not universally understood in the same way. It remains unclear how PPPs relate to specific financial policy or how they are built into national and international climate finance strategies. In turn this limits the ability of financial stakeholders to devise clear approaches and methods to engage in such partnerships, or on how to best evaluate and mitigate associated risk.

Secondly, it is essential to remember that we are talking about transformational thinking when discussing climate finance. It is clear then that public or private actors can not do this alone. Different actors throughout the value chain are needed and the different roles can't be compartmentalised so collaboration is needed.

Shifting to low carbon projects is difficult in light of unclear and/or changing public policies and strategies. Clarity on the value of low carbon projects and on potential risks is needed and financial stakeholders expect public actor to translate their strategies into clear criteria and objectives specific to PPPs. Private investments can be catalysed through building up a good level of confidence with private parties. A key mechanism for one stakeholder is to have a strong appraisal process, which can be seen as a guarantee of quality for the project, which is then likely to attract private investors.

The fund structure for PPP in climate finance has proved to enable broader flexibility and support for different projects at different stage and scales of development. For example, the German government - together with Deutsche Bank and KfW - established the Africa Agriculture and Trade Investment Fund (AATIF) in 2011. The Fund is an innovative public-private partnership dedicated to uplifting Africa's agricultural potential for the benefit of the poor. It aims to improve food security and provide additional employment and income to farmers, entrepreneurs and laborers alike by investing patiently and responsibly in efficient local value chains.

The approach is then to find suitable local projects and to directly connect with small developers on the ground. One of the major challenges 
is then the lack of track record which impedes small developers' access to funding as they do not comply with minimum bank requirements. A clear priority is to in increase the public sector's ability to identify bankable projects and then find the right partners with whom to co create a viable PPP. The public sector's investments are crucial in dealing with risk and leveraging private investments but there is a real issue with finding projects.

Risk-sharing in PPPs often means that private and financial stakeholders expect some incentives or risk reduction support from public parties. In particular, policy risk was deemed to be perhaps the single largest issue, and therefore stable policies and resulting PPP-specific strategies are urgently required.

From a private sector commercial aspect, it was suggested that the profitability of PPPs is limited due their complexity and high (policy) risk profiles. From a public sector point of view, it appeared that, while PPPs aim to deliver good value-for-money, practical experience shows that this is difficult to achieve.

To tackle profitability and value issues, interviewees noted that the development and implementation of clearer criteria, standards or evaluation methodologies is desirable. For private and financial actors, these are pivotal to enabling sound and robust assessment of PPPs and to strengthen the financial rationale. For public actors, it was noted that such criteria and standards can be essential to enable strict control and monitoting of the private sector's demands and expectations.

Lastly, significant cultural differences remain between public, private and financial actors, which are difficult to reconcile. The private sector remains cautious about government involvement because of perceived slowness and risk of politically motivated decision making. This can be made worse if private actors are only engaged at a later stage in the development of a PPP and lack deep understanding of the risks and rewards. A solution proposed for the UK Green Investment Bank (GIB) was to ensure there is an independent board and to demonstrate that, although publicly funded, the GIB is able to operate on commercial terms. PPPs are also often confronted with a strong resistance from civil society, which traditionally opposes the involvement of the private sector in public service delivery. To avoid those risks it is important to include public actors and stakeholders from the beginning. At the same time, PPPs, by definition, bring different actors together. They should therefore also be an engine of learning. 


\section{Discussion and key learnings}

The following section offers insights from our work in the context of public-private partnership for climate finance. It aims to stimulate reactions and thinking about what actions are needed next. By building on the evidence base about what works on the ground and what does not, we aim to provide preliminary lessons learned and recommendations from a public and private perspective.

\subsection{Lessons Learned}

Private investors are fundamental actors in funding the bulk of the transition to low-carbon, resilient economies. However, investments in developing markets and innovative technologies generally have higher capital costs and present new and unfamiliar risks that hinder the involvement of private actors.

PPPs have in several instances demonstrated their efficacy in overcoming this diversified range of risks, and their ability to accommodate climate investments needs. The theoretical background and the case studies suggest six lessons learned about what makes PPPs on climate finance effective from a public and private perspective.

\subsubsection{Stable regulatory environments are needed to attract substantial private investments}

Public intervention is necessary to mitigate policy risks such as unforeseen tax increases, and unstable revenues and costs. The GET FiT program in Uganda shows how lack of visibility and a changing regulatory environment can undermine the efficacy of PPPs. During the project's implementation, the Uganda government introduced a new tax legislation reducing benefits and incentives in different sectors. This created large uncertainty among private actors mainly fearing the revocation of value added tax (VAT) exemption for studies and supplies for hydro power plants and the impact of the removal of the initial capital allowance (deducting $75 \%$ of the capital expenditure from a company's profit). The concerns among developers and financiers was that such chang- 
es would have major impacts on the cost of projects and threaten their financial viability. KfW and the GET FiT Secretariat actively engaged the relevant stakeholders in order to obtain clarifications on the impacts of the bill and increase awareness on potential impacts for the development of renewable energies. The SPH system case study in Bangladesh provides an additional example of how stable and effective regulations promoting high-level of ownership among service providers, enabling long-term repayment term, extending warranty and suppliers accountability lead to an increase in the PPP's efficiency by enhancing the project sustainability and private sector trust in country's market potential. This examples illustrate how the private sector reacts to changes in the political, regulatory and legal frameworks.

\subsubsection{Provision of tailored technical assistance, capacity-building and awareness-raising can accelerate and ease private sector engagement}

A lack of capacity-building and awareness about potential costs and benefits is a critical barrier. PPPs for service delivery, especially those where the operator takes on some or all commercial risk, need to be carefully designed to ensure that investment/implementation commitments can be financed and that commercial partners can recover costs. This requires a solid knowledge based on, among others, market conditions, legislative procedures, state of infrastructures, and customers' needs and expectations. Developer needs, for instance, to understand permission and licensing processes, while investors need to understand the specifics for power purchase agreement.

There have been examples, however, of PPPs designed on the basis of poor information either because of lack of information sharing among parties or simply because data were inaccurate or missing. In this situation there is a risk that cost recovery may turn out to be lower than expected or investments need higher possibly leading to failures. This has been reflected in the Bangkok's Skytrain project where an implementation problem emerged due to positive data forecasting of 600,000 riders per day for the opening of the transportation system. The actual numbers were well below the predicted estimations with an initial of 150,000 followed by an increase of 380,000 riders per day. This inaccuracy has led to a series of financial problems and to near collapse of the service provider.

Recognizing the complexity of PPPs operating in the climate finance sphere and the need to strengthen the knowledge-base, several funds 
developed side-to-side to financial mechanisms technical assistance facilities. The Green for Growth Fund set up a Technical Assistance Facility supporting capacity-building and trainings as well as awareness raising. For instance, the facility helps GGF's partner institutions to develop internal capacities for sustainable RE lending, though, environmental and social gap analyses, RE project finance workshops including modules on the regulatory frameworks of the specific countries, technical aspects, project finance and risk management.

\subsubsection{Involvement of civil society or community groups enhances the efficacy of PPPs on the ground}

Context-specific evidence shows that PPPs which engage civil society or community groups tend to perform well in terms of delivery of specific services (e.g. energy and water supply) in developing countries where the so-called "poor households" constitute a large number of the customer share. These groups tend to have good knowledge of low-income areas and the needs of poor households, good relationships with the community and innovative solutions - based on direct experiences about how services can better meet needs. Their involvement can for instance improve provision by a utility or municipal government which may be unfamiliar with the local context. This is illustrated in the case of the SHS in Bangladesh where promoting a sense of ownership among consumers and the direct engagement of existing NGOs operating in rural Bangladesh has enabled the building of trust and has enhanced the reaching out of the project to remote customers improving overall revenue streams.

\section{Enabling risk allocation to the most suitable party is critical}

Private finance is a necessary component for fostering climate finance. However, while the private sector can move quickly where attractive returns are clear, profits appear to be not so readily apparent in the climate finance sector. Private sector activities in innovative market are generally burdened by market and opportunity costs. Investments in new markets, technologies and geographies imply higher capital costs and present new and unfamiliar risks. Equity investments, concessional loans, guarantees, and publicly provided or subsidized risk insurance can help to align public and private estimates of incremental costs and risk premia.

For instance, in the PPP model established for the Ouarzazate I, through a power purchase agreement the governmental Moroccan Solar Agency (MASEN) buys power from the partnership company at the cost 
of production and sell it to the power utility at much lower grid prices, directly assuming incremental costs and price risks that private investors were unwilling to bear. The Moroccan government and the international financial institutions fund the viability gap through an annual subsidy, positioning MASEN to create revenue certainty for the project developers, price certainty for the power utility as well as for consumers.

\section{Strong political commitment and analysis of PPP models and market viability is required}

The private sector will be interested in some PPP projects more than others based not only on purely financial considerations. National authorities have a major role to play in adding to the value of a PPP model. They have to signal the right political commitment in order to give private investors the market-confidence in long-term predictability and the value for money of climate-relevant investments. Certainly, the factors determining value for money for climate PPP will vary according to socio-economic contexts. However, a number of common trends which can be addressed and improved by governments exist including: reduced life cycle costs; better allocation of risk; faster implementation; improved service quality; and generation of additional revenue.

All these aspects represent the background against which private investors will assess whether or not to enter into partnership with the public sector. In the CDCF project in Bangladesh, (Installation of Solar Home Systems in Bangladesh) one could observe how the commitment of the local government, in terms of extended warranty and suppliers accountability, and engagement of local actors to increase efficiency and reduced governance and corruption risks, have contributed to broader the reach of the initiative behind what initially forecast. Similarly, the SMART tunnel project in Malaysia exemplifies how local authorities' high-level of engagement - through detailed analyses of the financial and market conditions, long-term commitment and development of an adequate budget planning, extensive monitoring activities - has led to the establishment of a successful value for money climate PPP model.

\section{Effectively tackling climate related externalities is needed to ensure the allocation of funds to low carbon projects}

Intervention to address the climate externalities and improve returns on climate-friendly investments through some forms of, for instance, carbon pricing are actions exerting high-level leverage for private investors. At the global level, in developed countries, robust carbon pricing has proved to provide incentives for significant private flows to developing countries through carbon offset markets (IMF, 2011). The same can be 
realized in the developing markets directly by advancing market commitments through feed-in-tariffs to subsidize renewable energy sources or improve energy efficiency through standards, codes or power sector reforms. Governments can also achieve broad leverage through actions that address key market failures, for example the public good externality that hampers innovation and dissemination of technologies. Drawing from the case studies presented in this report (e.g. GET FiT Program; the Ouarzazate Solar Power Plant in Morocco) it can be observed how a blend of grants, concessional, and carbon-offset financing can be used to provide an effective mixture of financial incentives and technical assistance that encourage private firms to invest in climate finance.

\subsection{Recommendations to negotiators}

\subsubsection{Recommendations}

Drawing on the research and dialogue, we propose the following eight recommendations for negotiators:

1. PPPs should play a role in climate finance and support both mitigation and adaptation activities. Climate finance needs are considerable and the coordinated efforts of public and private organisations are urgently required. PPPs provide valuable and adaptable conceptual frameworks to support cooperation and collaboration between public and private entities as well as means to increase public leverage of private climate finance if properly designed from the outset.

2. For PPPs to play a role, public authorities should develop enabling frameworks to support climate finance PPPs. PPPs require framework conditions to be in place that provide long-term visibility and stability to investors. These framework conditions should support de-risking of private finance, and, as indicated in our interviews, include PPPspecific legal and regulatory arrangements for example on how costs are recovered as well as transparent institutional responsibilities, clear public financial management, guidelines and oversight processes. The public sector further holds responsibility to identify objectives and formulate narratives that reconcile context-specific needs with both the specific characteristics and opportunities presented by PPPs and a sound investment framework for private finance.

3. Design of a PPP through a process of co-creation and early involvement of private financial institutions should be aimed for. PPPs often face dif- 
ficulties in implementation stages due to inadequate, unilaterally established processes. Co-creation and early private sector involvement are essential ingredients to ensure transparent and effective financial mechanisms are established, and that PPPs are developed in accordance with the characteristics and needs of all actors involved.

4. Mobility programs of staff between public and private financial institutions can be used to improve mutual understanding and communication. Communication difficulties are apparent that fragment the climate finance landscape and limit the scope of collaboration between public and private actors. Common interests, financial viability and societal imperatives require improved mutual understanding of the characteristics, needs and priorities of climate finance participants. Mobility programs whereby staff are exchanged for a period between different organisations may be an effective way to build bridges and reconcile the languages and understandings of public and private actors.

5. Public financial institutions could support risk-taking initiatives to enlarge the scope of bankable projects. Many potential fields of application of climate finance are characterised by high perceived risk and low levels of experience. Public financial institutions are best placed to overcome this barrier and the provision of first loss catalytic capital has a strong impact on leveraging private finance. Increased joint risktaking, supported by expert technical assistance, will support scaledup and accelerated deployment of climate finance.

6. Developed countries should support the emergence of PPPs in developing countries. Context-specificity is pivotal to the success of PPPs. The participation of local public and private stakeholders and financial institutions in the design and implementation process is needed to ensure adequacy to on-the-ground socio-economic and cultural realities and to support capacity building efforts.

7. Robust stakeholder consultation processes should be established and implemented. PPPs in climate finance are intimately tied to environmental, social and economic sustainability. This societal complexity, combined with their inherent requirements, warrants careful consultation of public, private as well as civil society stakeholders. In particular, the context-specific requirements of climate finance calls for interaction with local financial institutions and intermediaries. Further, PPPs aim to deliver public services and end-beneficiaries should be duly considered to ensure that climate finance PPPs address "on-the-ground" needs effectively. 
8. Systematic evaluation of implemented climate finance PPPs should be encouraged. The case studies identified in this study illustrate how certain objectives can be met by PPPs in climate finance. However, there is a lack of rigorous evidence, particularly in developing countries, as to whether they are the most effective way to deliver those objectives. More systematic evaluation of real examples of PPPs would contribute to greater interest in their use and also help identify more specific success factors. 



\section{Works Cited}

ADB. (2008). Public-Private Partnership Handbook. Manila: ADB.

ADBI. (2011). Appropriate financial instruments for public-private partnership to boost cross-border infrastructural development - EU experience. Tokyo: Asian Development Bank Institute.

Bank, T. W. (2010). World Development Report 2010: Development and Climate Change. Washington D.C.: The World Bank.

CPI. (2014). The Global Landscape of Climate Finance 2014. Climate Policy Initative.

CPI. (2014). What is climate finance? Definitions to improve tracking and scale up climate finance. Climate Policy Initiative.

EC. (2003). Guidelines for successful Public-Private Partnerships. Brussels: European Commission.

Ecofys. (2010). Options for Pooling and Sequencing Private and Public funds for performance-based payments in REDD.

GGBP. (2014). Green Growth in Practice: Lessons from Country Experiences. Seoul: Green Growth Best Practice.

ICCG. (2014, April). Public-Private Partnerships: a focus on energy infastructures and green investments. ICCG Reflection No. 22.

IEA. (2011). Joint Public-Private Approaches for Energy Efficiency Finance: Policies to Scale-Up Private Sector Investment. Paris: International Energy Agency.

IEA. (2013). World Energy Outlook 2013. Paris: International Energy Agency.

IFC. (2011). Public Private Equity Partnerships: Accelerating the Growth of Climate Related Equity Investment. Washington D.C.: International Finance Corporation.

ODI. (2011). Leveraging private investment: the role of public sector climate finance. London: Oversea Development Institute.

OECD-IEA. (2014). The Role of the 2015 Agreement in Mobilising Climate Finance. Paris: OECD, Climate Change Expert Group, Paper No. 2014(7).

SCF. (2014). 2014 Biennial Assessment and Overview of Climate Finance Flows Report. Bonn: UNFCCC Standing Committe on Finance.

UNEP, S. B. (n.d.). Private Financing of Renewable Energy - a Guide for Policymakers.

World Bank. (2010). World Development Report 2010: Development and Climate Change. Washington D.C.: The World Bank.

World Bank. (2012). Public-Private Partnerships, a Reference Guide version 1.0. Washington DC: World Bank Institute and Public-Private Infrastructure Advisory Facility.

WRI. (2012). Moving the fulcrum: a primer on public climate financing instruments used to leverage private capital. Washington DC: WRI. 



\section{Sammenfatning}

\section{Problem-og undersøgelsesmålsætning}

Der er stærke indikationer for det presserende behov for opskalering af klimafinansiering til at afbøde drivhusgasser i overensstemmelse med $2{ }^{\circ} \mathrm{C}$-målsætningen og for at støtte implementering af beskyttelsen af det internationale samfund mod følgerne af et skiftende klima. Selv om offentlige aktører har et ansvar for at iværksætte klimafinansiering, er det klart, at bidraget fra den private sektor må være betydeligt. Derfor er et stærkt offentligt engagement nødvendigt for at involvere den private sektor og sikre, at klimafinansiering realiseres og udføres effektivt. I denne sammenhæng er offentlige-private partnerskaber (OPP) i klimafinansiering en lovende tilgang til at bidrage med leveringen af klimafinansiering.

Denne rapport bygger på en litteraturgennemgang, casestudier og dialog mellem interessenter for at vurdere den potentielle rolle af klimafinansiering for $O P P$, der sigter mod at: bidrage til en bedre forståelse af effektive midler for den offentlige sektor til udnyttelse af støtte fra den private sektor for klimaindsatsen, identificere rolle og potentiale af OPP i klimafinansiering, fremhæve eksempler og casestudier, samt anvende erfaringer til støtte for klimaforhandlinger og effektiv anvendelse af OPP i fremtiden.

\section{OPP karakteristika og potentiale}

OPP i klimafinansiering kan defineres som samspil mellem offentlige og private finansielle institutioner til levering af klimafinansiering. OPP sigter mod at give offentlig serviceformidling, og selv om de søger at drage fordel af gensidigt fordelagtige partnerskaber, forbliver de baseret på offentligt tilsyn. De sørger derfor for rammer til at sikre offentlig ledelse og ansvarlighed i håndtering af klimaændringerne, samtidig med at formidle ejerskabet af bestemte dele af klimafinansieringen til private hænder.

OPP indebærer normalt tre centrale elementer: formaliseret partnerskab, der definerer de respektive roller og ansvar for offentlige og private aktører, risikodeling mellem offentlige og private aktører, samt finansiel belønning for private parter i overensstemmelse med aftalevilkår og risikodelingsordninger. De kan betragtes som formelle part- 
nerskaber afgrænset af et særligt kontraktforhold mellem offentlige og private parter. Mere generelt kan de også formidle samarbejdsmekanismer mellem offentlige og private enheder eller forstås i forhold til behovet for, at offentlige myndigheder udnytter privat finansiering. De tilbyder derfor både praktiske og konceptuelle løsninger til klimafinansiering for at sikre et produktivt samspil mellem offentlige og private finansieringsorganisationer.

\section{Anvendelighed og eksempler}

OPP i klimafinansiering har en række anvendelsesmuligheder. Hidtil har afbødning tiltrukket størstedelen af den offentligt-private klimafinansiering, men tilpasning er også relevant, forudsat at udfordringer såsom rentabilitet eller risikostyring kan overkommes. OPP kan gennemføres i forskellige skalaer fra individuelle projekter til finansielt fondsniveau. Disse repræsenterer forskellige stadier og skalaer for klimafinansiering. Områder som grøn infrastruktur, herunder byudvikling, forvaltning af naturressourcer og innovation synes særligt velegnede til offentligtprivat samarbejde. Bymiljøer giver også interessante muligheder for OPP i klimafinansieringen, da de karakteriseres af nærhed og samspil mellem offentlige og private interessenter til levering af offentlige tjenester. Endvidere er OPP lovende i u-lands- og nye økonomier, og mekanismer såsom outputbaseret støtte (en form for resultatbaseret finansiering) kan fremme gennemførelsen af fattigdomsorienteret OPPklimafinansiering.

En række eksempler giver indblik i potentialet af OPP til klimafinansiering. Men systematisk evaluering af succesen med OPP som en mekanisme er, især i udviklingslandene, forholdsvis begrænset. Fem casestudier præsenteres i denne rapport for at illustrere deres potentiale:

- Green for Growth Fund er et eksempel på en differentieret finansiel mekanisme, der udnytter offentlige og private midler til støtte for energieffektivitet og vedvarende energiprojekter.

- Community Development Carbon Fund er en OPP-fond, der overvandt de traditionelle begrænsninger på kulstofsmarkeder til støtte for finansieringen af små projekter for fattige.

- GET FiT program, gennemført i Uganda, illustrerer, hvordan OPP kan støtte risikoafbødning indenlands og fremme private investeringer $\mathrm{i}$ vedvarende energy. 
- Kuala Lumpurs Stormwater Management Road and Tunnel giver et eksempel på en succesfuld OPP-infrastruktur, der både fungerer som afbødning og tilpasning.

- Moroccan Ouarzazate solar project illustrerer, hvordan OPP kan fungere effektivt som udviklingsprojekt for vedvarende energi under offentlig ledelse.

\section{Rammebetingelser}

En voksende mængde litteratur, OPP-eksempler og dialog med de berørte parter, giver værdifuld indsigt i rammebetingelserne for OPP i klimafinansiering. Tre centrale drivkræfter blev identificeret til implementering af OPP: forstærket "værdi for pengene", gennem tildeling af forskellige risici for de parter, der er mest egnede til at håndtere dem, hvilket resulterer $\mathrm{i}$ reducerede omkostninger gennem projektets livscyklus, forbedret gennemførelse og servicelevering, der nyder godt af de specifikke og komplementære egenskaber af offentlige og private aktører, og øget finansiel gennemslagskraft støttet af en række politiske og finansielle instrumenter, der kan anvendes i klimafinansiering for OPP.

Selv om der er etableret positive eksempler, forbliver mainstreaming af OPP i klimafinansiering begrænset, og det er klart, at en fortsat indsats er nødvendig for at fjerne forhindringerne for deres implementering. Der er flere vigtige forhindringer for udbredelsen af OPP i klimafinansiering, herunder: usikkerhed om implementeringen af de institutionelle og finansielle kanaler fastlagt ved klimaforhandlingerne, høj risikovurdering ved klimaprojekter især i udviklingslandene, og den begrænsede adgang til klart formulerede offentlige politikker. Kulturelle forskelle mellem offentlige og private finansielle institutioner er også en bekymring, og fra den private sektors synspunkt opfattes OPP ofte som værende kompleks og tilbyde begrænset rentabilitet.

Det er nødvendigt med etablering af robuste rammer for at støtte OPP i klimafinansieringen for at overvinde disse forhindringer. Stabile juridiske og lovgivningsmæssige rammer er nødvendige for at gøre det muligt for regeringer at indgå i OPP og formidle synlighed og klarhed for private aktører. Offentlig ledelse i klimafinansiering opfordrer også til klart formulerede mål og anvendelsesområder for OPP, således at roller og ansvarsområder klart kan afgrænses. Endelig er effektiv og gennemsigtig offentlig økonomistyring og tilsyn nødvendigt for at støtte risikoreduktion og sikre den private sektors deltagelse.

Andre succesfaktorer omfatter offentlige og private aktørers vilje til at samarbejde, hvilket kræver forbedret kommunikation og bestræbelse på at 
gennemføre en samskabelsesproces fra tidlige udformningsstadier. Bestræbelser på finanskapacitetsopbygning kombineret med involvering af interessenter er endvidere afgørende for at sikre lokalt engagement og deltagelsen af lokale finansielle formidlere til at finde lokalt hensigtsmæssige løsninger, der opfylder behovene "på stedet" for slutmodtagere.

\section{Anbefalinger}

Med erfaring fra forskning og dialog, foreslår vi følgende otte anbefalinger til forhandlere.

1. OPP bør spille en rolle i klimafinansiering og støtte både afbødnings- og tilpasningsaktiviteter. Behovene for klimafinansiering er betydelige, og der er et presserende behov for koordinerede indsatser fra offentlige og private organisationer. OPP giver værdifulde og fleksible konceptuelle rammer til støtte for samarbejde og samspil mellem offentlige og private enheder, såvel som midler til at øge den offentlige ydelse af privat klimafinansiering, hvis den er korrekt udformet fra starten.

2. For at OPP kan spille en rolle, bør de offentlige myndigheder udvikle aktiveringsrammer til at støtte OPP-klimafinansiering. OPP kræver rammebetingelser, der skal være på plads, og som giver langsigtet synlighed og stabilitet for investorerne. Disse rammebetingelser bør støtte risikominimering for privat finansiering og, som angivet i vores interviews, omfatte OPP-specifikke juridiske og lovgivningsmæssige ordninger om f.eks. hvordan omkostningerne dækkes, samt transparent institutionelt ansvar, klar offentlig økonomistyring, retningslinjer og tilsynsprocesser. Den offentlige sektor har ydermere ansvaret for at identificere mål og formulere rapporter, der forener kontekstspecifikke behov med både de særlige karakteristika og muligheder repræsenteret af OPP og en sund investeringsramme for privat finansiering.

3. Udformningen af OPP gennem en proces med samskabelse og tidlig inddragelse af private finansielle institutioner bør tilstræbes. OPP møder ofte vanskeligheder i implementeringsfaser, hvilket skyldes utilstrækkelige, ensidigt etablerede processer. Samskabelse og tidlig deltagelse af den private sektor er væsentlige ingredienser for at sikre, at gennemsigtige og effektive finansielle mekanismer etableres, og at OPP udvikles i overensstemmelse med alle involverede aktørers karakteristika og behov.

4. Mobilitetsprogrammer for medarbejdere mellem offentlige og private finansielle institutioner kan bruges til at forbedre den gensidige for- 
ståelse og kommunikation. Kommunikationsvanskeligheder fragmenterer tydeligt klimafinansieringslandskabet og begrænser omfanget af samarbejde mellem offentlige og private aktører. Fælles interesser, finansiel levedygtighed og samfundsmæssige krav kræver bedre gensidig forståelse af karakteristika, behov og prioriteringer for deltagerne i klimafinansiering. Mobilitetsprogrammer, hvorved der udveksles medarbejdere for en periode mellem forskellige organisationer, kan være en effektiv måde til at bygge bro og forene sprog og forståelse mellem offentlige og private aktører.

5. Offentlige finansielle institutioner kan understøtte risikovillige initiativer til udvidelse af anvendelsesområdet for bankfinansierede projekter. Mange potentielle anvendelsesområder for klimafinansiering kendetegnes ved opfattelsen af høj risiko og lavt erfaringsniveau. Offentlige finansielle institutioner er bedst egnede til at overvinde denne forhindring, og tilvejebringelsen af katalytisk kapital mod tidlige tab har en kraftig indvirkning på tilvejebringelsen af privat finansiering. Øget fælles risikovillighed støttet af faglig ekspertbistand vil støtte den opskalerede og accelererede udbredelse af klimafinansiering.

6. De industrielle lande bør støtte fremkomsten af OPP $\mathrm{i}$ udviklingslande$n e$. Kontekst specificitet er afgørende for succes med OPP. Der er behov for deltagelse af lokale offentlige og private interessenter og finansielle institutioner i udformnings- og gennemførelsesprocessen for at sikre tilstrækkelige socioøkonomiske og kulturelle realiteter på stedet og støtte bestræbelserne på kapacitetsopbygning.

7. Høringsprocesser af interessenter bør etableres og implementeres. OPP i klimafinansiering er tæt knyttet til miljømæssig, social og økonomisk bæredygtighed. Denne samfundsmæssige kompleksitet, kombineret med de iboende forpligtelser kræver omhyggelig høring af offentlige, private samt civilsamfunds-interessenter. Især kontekstspecifikke krav til klimafinansiering kræver interaktion med lokale finansielle institutioner og formidlere. Endvidere sigter OPP mod at levere offentlige tjenester, og slutmodtagere bør vurderes grundigt for at sikre at OPP-klimafinansiering adresserer behovene på stedet mest effektivt. 
8. Der bør tilskyndes til systematisk evaluering af implementeret OPPklimafinansiering. Casestudierne i denne undersøgelse viser, hvordan visse mål kan opfyldes ved OPP i klimafinansiering. Men der er mangel på stringent bevismateriale, navnlig i udviklingslandene, for, om det er den mest effektive måde til at levere disse mål. Mere systematisk evaluering af reelle eksempler på OPP vil bidrage til større interesse for deres anvendelse og også hjælpe med at identificere mere specifikke succesfaktorer. 


\section{Appendix 1: Detailed Case Studies}

\section{Green for Growth Fund (GGF)}

\section{Overview and stakeholders}

The Green For Growth Fund (GGF) Southeast Europe was established in December 2009 as a public-private partnership aiming to achieve a $20 \%$ reduction in energy consumption and/or a $20 \%$ reduction in $\mathrm{CO} 2$ emissions in the target region by 2020, in line with the Europe-2020 initiative. The GGF's organizational structure includes a range of donors, international financial institutions and private investor. ${ }^{9}$

\section{Application}

The Fund has been developed and designed to be complementary to existing programs and funding sources, bridging knowledge gaps and acting as a local market enabler through the provision of direct financing as well as via partnering with financial institutions. As a public-private partnership, GGF can leverage donor funds and funds from international financial institutions, to access private capital.

\section{Design}

GGF's financial mechanism is two-fold

- refinancing financial institutions in Southeast Europe by providing credit lines for on-lending to private households, homeowners

\footnotetext{
${ }^{9}$ It was initially established by the European Investment Bank together with the KfW Entwicklungsbank followed by the European Bank for Reconstruction and Development. Leading donors of the fund are the European Investment Fund (EIF), the German Federal Ministry for Economic Cooperation and Development (BMZ), the Oesterreichische Entwicklungsbank (OeEB), and the Development Bank of Austria. International Financial Institutions partners are the European Investment Bank, KfW, the European Bank for Reconstruction and Development, IFC, OeEB, FMO, and the Netherlands Finance Company. While, private investors so far include the German private bank Sal. Oppenheim and the asset management firm Finance in Motion.
} 
associations, businesses, municipalities and public sector entities in order to finance energy efficiency measures and renewable energy projects

- providing direct financing loans to non-financial institutions, such as renewable energy companies, energy service companies, small scale suppliers of energy efficiency and renewable energy services and equipment suppliers.

In the PPP model, national governments or donor agencies provide an investment in the most junior tranche (the "C shares") to absorb losses that the investments made by the Fund might incur. The next financial layer is taken up by international financial institutions and multilateral development banks that, although created and supported by the public sector, seek to provide market returns on their investments. This mezzanine tranche (the "B shares") also serves to absorb any losses that might exceed the amount of $C$ shares available in the structure. These two layers provide a risk cushion that enables the GGF to issue senior securities ("A shares") and notes to private investors. ${ }^{10}$ The tiered risksharing structure used by the GGF is particularly attractive to multilateral and private investors investing commercial capital.

\section{Implementation}

In 2012, the GGF expanded its geographical reach from its core region of the Western Balkans, including Turkey, to include five countries in the European Eastern Neighbourhood Region, bringing the total to thirteen countries.

The most common types of measures financed are energy-efficient process-related equipment for businesses and improvements to buildings, primarily insulation and modern windows, for both households and businesses. ${ }^{11}$

The table below provides a snapshot of some projects implemented in Bosnia and Herzegovina and Albania.

10 http://www.ggf.lu/fileadmin/user_upload/05_downloads/broschures/ggf-general-brochure-2013.pdf

${ }^{11} \mathrm{http}: / /$ www.ggf.lu/fileadmin/user_upload/05_downloads/annual_reports/ggf-annual-report-2013.pdf 
Table 1: Overview of selected projects under the GGF

\begin{tabular}{|c|c|c|c|}
\hline $\begin{array}{l}\text { Country and } \\
\text { Budget }\end{array}$ & Project Focus & Financing & $\begin{array}{l}\text { Achieved/Expected Out- } \\
\text { comes }\end{array}$ \\
\hline $\begin{array}{l}\text { Bosnia and } \\
\text { Herzegovina } \\
\text { EUR } 10 \text { million }\end{array}$ & $\begin{array}{l}\text { Support the development } \\
\text { of an energy efficiency } \\
\text { lending product within the } \\
\text { institution, enabling } \\
\text { households in Bosnia and } \\
\text { Herzegovina to reduce } \\
\text { energy costs, consumption } \\
\text { and } \mathrm{CO} 2 \text { emissions. }\end{array}$ & $\begin{array}{l}\text { Credit line to strengthen the } \\
\text { UniCredit Bank a.d., Banja } \\
\text { Luka lending capacity for } \\
\text { energy efficiency (EE) pro- } \\
\text { jects at the retail, micro, } \\
\text { small and medium enterprise } \\
\text { (MSME) levels }\end{array}$ & $\begin{array}{l}\text {-Projected annual reduction } \\
\text { of energy consumption over } \\
37,000 \mathrm{MWh} \text {. } \\
\text {-Projected annual reduction } \\
\text { of } \mathrm{CO} 2 \text { emissions over } 30,860 \\
\text { tons. }\end{array}$ \\
\hline $\begin{array}{l}\text { Albania } \\
\text { EUR } 9.1 \text { million }\end{array}$ & $\begin{array}{l}\text { Support the construction } \\
\text { and operation of the Len- } \\
\text { garica small hydro project, } \\
\text { enabling the country to } \\
\text { reduce its dependency on } \\
\text { electricity imports with } \\
\text { clean energy investments }\end{array}$ & $\begin{array}{l}\text { GGF and OeBD provided } \\
\text { direct financing loan to the } \\
\text { Austrian enso hydro } \mathrm{GmbH} \\
\text { which erected the small } \\
\text { hydropower plant }\end{array}$ & $\begin{array}{l}\text { The plant will have a capacity } \\
\text { of just over } 9 \text { megawatts. } \\
\text { Average annual power pro- } \\
\text { duction is projected to reach } \\
\text { about } 32 \text { gigawatt-hours, } \\
\text { enough to power approxi- } \\
\text { mately } 10,000 \text { Albanian } \\
\text { households }\end{array}$ \\
\hline
\end{tabular}

\section{Outcomes}

Since its inception, GGF has financed nearly 10,000 investments in EE and RE measures that have enabled overall savings over 671,000 MWh of energy and 176,000 tons CO2 emissions reduction per year. Project outcomes are monitored through an innovative online tool called "eSave" enabling an easy calculation of environmental impacts achieved by the proposed investments, complementing the more complex monitoring approach of energy auditors. This has enabled GGF members to gather and report accurate energy savings and emission reduction information.

\section{Lessons learned and Recommendations}

According to GGF, achieving higher energy and emission reduction, builds upon a combination of robust financial mechanisms and technical assistance. It is necessary to develop PPP models that include:

- Capacity-building in terms of financial products and marketing strategy development.

- Awareness-raising to fill the knowledge gaps about the benefits and opportunities of EE/RE related investments.

- Showcasing of existing good practice examples to demonstrate the benefits of RE and EE investments. 
- Establishment and implementation of new or enhanced Environmental and Social Procedures including training sessions.

\section{Community Development Carbon Fund (CDCF)}

\section{Overview and Stakeholders}

The Community Development Carbon Fund evolved from a proposal by the Secretariat of the UNFCCC and the International Emissions Trading Association (IETA), advising the World Bank to address the special needs of small countries through a tailored fund mechanism. The CDCF was officially established in 2003 as a PPP involving 9 governments and 16 private firms, ${ }^{12}$ administered by the World Bank, and with a total capitalization of USD 128.6 million.

\section{Application}

The Clean Development Mechanism (CDM) portfolio is traditionally dominated by larger scale industrial projects for which contribution towards climate change and sustainable development are often framed in terms of technology transfer and general contribution towards economic growth. Relatively few projects across the CDM portfolio however offer direct local livelihood benefits. CDCF aims to address this gap by promoting a suitable financial environment for small communities, by linking private investors with small-scale development projects, which are usually at a disadvantage when competing for carbon finance, to overcome barriers linked to higher business costs and risks. Accordingly, the fund provides carbon finance to small-scale projects simultaneously benefitting local communities and abating greenhouse gas emissions in least developed countries (LDCs) and poor areas in all developing countries.

\section{Design}

Usually, CDCF projects are developed to address welfare of poor local communities through the generation of direct co-benefits, arising from

12 Governments of Austria, Canada, Italy, Luxembourg, the Netherlands and Spain; regional governments of Brussels and Wallonia (Belgium); companies and organizations: BASF, Daiwa Securities SMBC Principal Investments, EdP, Endesa, Fuji Photo Film Co. Ltd., Göteborg Energi AB, Hidroeléctrica del Cantábrico, IBRD as Trustee of the Danish Carbon Fund, Idemitsu Kosan, KfW, Nippon Oil Corporation, Okinawa Electric Power Co., Rautaruukki, Gas Natural, Statkraft Carbon Invest AS, Statoil ASA, Swiss Re. 
the project itself, and bridging deficits in infrastructure, services, employment and livelihoods. When there are limited or no identifiable direct co-benefits, a separate Community Benefits Plan (CBP) is prepared in consultation with the beneficiary communities and funded out of a premium on carbon credit prices ("indirect co-benefits"). CBP monitoring and reporting is, therefore, integral to the legal requirements under the Emission Reduction Purchase Agreements (ERPAs). CDCF donors acquire a pro rata share of emissions reductions from purchase agreements signed with host country governments or project sponsors.

\section{Implementation}

As of October 2013, the CDCF portfolio comprised of 22 active CDM projects, of which 13 provide indirect community benefits (e.g. proved working conditions and livelihoods of waste pickers; construction of local infrastructure; improved local agricultural production; access to electricity for poor isolated rural households and communities) and 9 generate direct community benefits (e.g. cheaper, safer and more reliable energy for cooking in poor rural homes; provision and installation of energy efficient lighting (CFLs) in rural areas; improved heating service in public buildings).

\section{Outcomes}

In 2013 CDCF reported a fund capitalization of USD 118 million, with average projects size of 255,000 carbon credits (tCO2e). The total project portfolio was equal to 5,600,000 carbon credits (tCO2e). A wide range of technologies were implemented within CDCF projects to generate carbon credits.

\section{Lessons learned and Recommendations}

CDCF fosters the creation of a financing environment for the poorest countries communities that are otherwise bypassed by carbon investors. Building upon CDCF unique experience in using carbon finance to support the development priorities of low-income countries, several lessons and recommendations can be drawn:

- Innovative approaches and increased public support are necessary to provide upfront capital investment while simultaneously mitigating risks. 
- More clarification and simpler rules for CDM procedures are required.

- Supporting policy and institutional frameworks are needed to ensure scalability and sustainability of projects.

Particularly beneficial to the implementation of the PPP models are:

- The distinction between direct and indirect project benefits and the development of Community Benefit Plans integrated within the social corporate responsibility of the project.

- The Community Benefit Plan participatory approach and monitoring indicators proved to be very valuable, both in terms of developing a cooperative and trusting relationship between local communities and between public and private actors engaged in the PPP model.

\section{CDCF Project example: Installation of Solar Home Systems in Bangladesh}

In Bangladesh, approximately $32 \%$ of the total population has access to grid electricity, and $18 \%$ of total household consumption is spent on fuel, as households use kerosene lamps for lighting and batteries to run television sets and other small appliances. The government undertook diversified actions to improve energy accessibility and use levels. It established the Infrastructure Development Company, Ltd (IDCOL) that developed a solar home system (SHS) using photovoltaic panels to produce electricity.

The SHS scheme targets poor Bangladeshis living in remote areas that grid electricity is not expected to reach in the foreseeable future. The model provides a diversified collection of SHS to consumers - ranging from 10 to 135 Watt systems. It uses a dealer credit model based on the following steps:

1. Households are required to make a down payment equivalent to at least $10 \%$ of the system cost-net of subsidy. The remaining $90 \%$ is financed by a loan at market rates, which households obtain through partner organisations (POs).

2. On receipt of the down payment, the POs enter into a sale/lease agreement with a supplier. The POs receive three months' credit from the supplier and install the systems. 
3. After installation, the PO applies to IDCOL to refinance the loan and grant. IDCOL verifies that the system has been installed properly and then provides a grant to the $\mathrm{PO}$ equal to the entire amount of the subsidy. On receiving the funds from IDCOL, the PO pays back the credit received from the supplier. IDCOL also refinances $60 \%$ to $70 \%$ of the loan amount.

4. The World Bank, the Asia Development Bank (ADB), the Islamic Development Bank (IDB), and other partners provides credit support. Meanwhile, the Global Partnership on Output-Based Aid (GPOBA), the German development institution (GIZ), and the German development bank (KfW) provides output-based aid (OBA) subsidy in the amount of USD28 for all sizes of SHS to reduce the cost of SHS for consumers.

The overall financing structure of the SHS scheme is shown the following table.

\begin{tabular}{|c|c|c|c|c|c|}
\hline & & $20 W p$ & $40 W p$ & $50 W p$ & $65 \mathrm{Wp}$ \\
\hline System cost & Cost & 175 & 317 & 396 & 486 \\
\hline OBA subsidy & Fixed at USD 28 & 28 & 28 & 28 & 28 \\
\hline $\begin{array}{l}\text { System cost ne } \\
\text { of grant }\end{array}$ & $\begin{array}{l}\text { Cost of system after capital buy-down } \\
\text { using GPOBA grant }\end{array}$ & 147 & 289 & 368 & 458 \\
\hline $\begin{array}{l}\text { Household down } \\
\text { payment }\end{array}$ & $10 \%$ of system cost net of grant & 15 & 29 & 37 & 46 \\
\hline Credit from PO & $\begin{array}{l}\text { The remaining system cost is financed by } \\
\text { micro-credit: } 20-30 \% \text { by PO and } 60-70 \% \\
\text { by IDCOL }\end{array}$ & 40 & 78 & 99 & 124 \\
\hline $\begin{array}{l}\text { IDCOL refinanc- } \\
\text { ing }\end{array}$ & $\begin{array}{l}70 \% \text { of microcredit financed by IDCOL is } \\
\text { provided by IDA }\end{array}$ & 93 & 182 & 232 & 289 \\
\hline
\end{tabular}

Source: Kumar and Sadeque 2012.

Starting with an target of 50,000 systems, the program had installed more than 2.9 million SHS by March 2014, benfiting an estimated 13 million people. The SHS generated approximately $130 \mathrm{MW}$ leading to fossil fuel savings of 172,000 ton and 503,000 ton emissions reduction annually. Additionally, direct community benefits include 60.000 jobs, as well as healthier and safer home and working environments.

This example provides interesting insights on key challenges and success factors related to the PPP model: 
- Overcoming the affordability barrier for households and fostering a sense of ownership among consumers has insured a widespread adoption of SHS as well as proper use, maintenance and upkeep.

- The inclusion of a refinancing mechanisms allows POs to provide loans with longer repayment terms (up to 3 years compared to the usual 6 months) which reduces consumers' monthly payments leading to increase affordability.

- The provision of tailored technical assistance from various donors (including GEF and GPOBA) has supported IDCOL's efforts to establish a market for SHS and further support the management of the program.

- The engagement of existing NGO/MFI operators in rural Bangladesh to operate as SHS vendors has enabled to reach out to remote customers in a cost-effective way.

- The shifting performance to POs and suppliers increased the sustainability of the project by mitigating governance and corruption risks.

Key recommendations to replicate or up-scale the project can be summarized, as follows:

- Develop innovative financing mechanisms deploying high-level of ownership and enabling long-term repayment terms.

- Plan financial contribution from all parties to ensure effectively and timely implementation.

- Extend warranty and suppliers accountability to increase efficiency and reduced governance and corruption risks.

- Engage local actors to cost-effectively reach out and engage end consumers.

\section{GET FiT program in Uganda}

\section{Overview and stakeholders}

In 2010 the United Nations Secretary General's Advisory Group and Climate Change (AGECC) approached the Deutsche Bank Climate Change Advisors (DBCCA) to develop innovative concepts to drive renewable 
energy investments in developing regions. DBCCA responded by creating the so called Global Energy Transfer Feed-in Tariffs Program (GET FiT), an international PPP aiming to assist East African nations in pursuing a climate resilient low-carbon development path. The GET FiT program is supported by the Government of Norway, the United Kingdom, the Government of Germany and the European Union through the EU Africa Infrastructure Fund as well as by the World Bank through their IDA Partial Risk Guarantee (PRG) instrument.

\section{Application}

GET FiT builds upon the concept that governments in the developed world and/or multilateral organisations can support the upgrading of existing regulatory frameworks in emerging economies to improve the risk profile and commercial viability of renewable energy from a private investor's point of view. GET FiT is centred around three main pillars:

- Public support for renewable energy incentives.

- Mitigation of risks through international guarantees and insurance.

- Coordination and provision of technical assistance.

The program GET FiT supports private sector investments in capital intensive renewable energy sources, creating an "enabling environment" by increasing transparency and visibility and reducing opportunity costs in new markets.

\section{Design}

Roll-out of the Program has formally started in Uganda in 2013 to simultaneously leverage private investment into renewable energy generation projects, and target key barriers for investors looking at potential investments in small renewable energy projects (1-20 MW). Its main aim is to fast-track a portfolio of about 20-25 small-scale renewable energy (RE) generation projects, with a total installed capacity of up to $170 \mathrm{MW}$. The main financial feature of the Program is a front-loaded results-based premium payment. The top-up payment is provided to projects in terms of USDc/kWh (USDc 1.4/kWh for hydropower and USDc 1.0/kWh for biomass and USDc $0.5 / \mathrm{kWh}$ for bagasse) for actual delivery of energy to the national grid over 20 years. The intention behind this payment flow setup is to foster commercial lending by providing additional cash flow to project owners during critical (early) debt repayment periods. 


\section{Implementation}

As a result of power and fuel supply shortages, between 2006 and 2008, Uganda saw its GDP growth reduced from 6-6.5 to $4.5 \%$. While the Ugandan power sector has undergone considerable reform to face shortages problems, several key challenges remain in terms of attracting investments particularly in small renewables:

- Unreliable enabling environment for private investors. The World Bank ranked Uganda 132 out of 189 in the World Bank's Doing Business index (2014).

- Insufficient political and economic incentives.

- High demand on the government of Uganda.

The GET FiT program has been implemented to overcome these barriers by: i) timely commissioning of up to $170 \mathrm{MW}$ of renewable energy capacity (until 2018) representing a $21 \%$ increase relative to current installed capacity; ii) avoiding significant costs for the sector as well as emissions from fossil fuel generation; iii) improving overall sector performance and investment attractiveness; iv) enabling a sustainable exit, with costreflective and Renewable Energy Feed-in Tariff (REFiT) levels, and finally; v) improving sector regulation.

\section{Outcomes}

In 2014, the GET FiT Secretariat announced the approval of four solar PV projects that will be developed with the support of the GET FiT Solar Facility, introducing a solar PV capacity of $20 \mathrm{MW}$ to the Ugandan national grid. The completion of the plants is planned by early 2016 . Hence, with the $108 \mathrm{MW}$ represented by the 13 projects (biomass, bagasse and hydropower) previously approved, the GET FiT portfolio now stands at a promising $128 \mathrm{MW}$ of planned renewable energy.

\section{Lessons learned and Recommendations}

During the course of GET FiT implementation, several challenges have been:

- Lack of adequate grid investments to ensure adequate interconnection and power evacuation.

- Lack of a stable regulatory environment signalled by the introduction of a new tax legislation reducing tax benefits and incentives in different sectors. This created uncertainty among developers who mainly feared the revocation of value-added tax (VAT) exemption for 
studies and supplies for hydro power plants and the impact of the removal of the initial capital allowance (allowing for a deduction of $75 \%$ of the capital expenditure from a company's profit). KfW and the GET FiT Secretariat actively engaged with the relevant stakeholders to obtain clarification on the impacts of the bill and increase awareness among local actors and key investors.

Key recommendations to foster the up-take and replicability of similar projects can be summarized as follow:

- Legal and regulatory aspects, such as new tax legislation, national and international standards require close monitoring and timely know-how assistance for local partners and private investors.

- Unexpected technical difficulties require higher forecasts in terms of investment costs.

- Stable financial and political environments are important throughout the projects' lifespan to ensure effective and timely running and completion of activities.

\section{The Stormwater Management and Road Tunnel (SMART)}

\section{Overview and Stakeholders}

Since the early 1980s Kuala Lumpur has witnessed rapid population and economic growth. This rapid urbanization has resulted in a marked increase in the frequency of flash flooding in the central areas of the city. The Malaysian government monitored the situation and initially developed the Klang River Basin Flood Mitigation project. The project aimed to control flooding by creating holding ponds and increasing river channel capacity. This first attempt has however had only limited success. Therefore, in 2001 the Malaysian government responded by launching a call for innovative proposals to tackle this challenge, generating the mixed-used tunnel idea. Because of liability reasons, the tunnel had to run below government-owned land, which led planners to the idea of establishing a PPP between the Malaysian government, and two private companies (an engineering and construction-company, and a mining company). 


\section{Application}

The Stormwater Management and Road Tunnel (SMART) was developed as a concession. The tunnel would divert and store the storm water, and allow traffic flow when empty of water. The tunnel operates in three different modes to meet the needs of Kuala Lumpur traffic and prevent flooding. In two of the modes, cars can continue to use the motorway tunnel and storm water is stored in holding ponds and under the motorway portion. In the third mode, the tunnel is closed to traffic and storm water is diverted into all levels of the tunnel. Once the flooding problem has passed, and water has drained, the tunnel is dried, cleaned of debris, and reopened to traffic, all within 48 hours of the tunnel closing.

\section{Design}

The joint venture portion of the PPP is composed of the two private Malaysian companies, with each partner owning 50\%. The joint venture was the turnkey contractor for the project and formed the Syarikat Mengurus Air Banjir and Terowong Sdn Bhd (or SMART Sdn Bhd) company as the concessionaire. SMART Sdn Bhd signed a 40 year concession with the Malaysian government, the Malaysian Highway Authority and the Department of Irrigation and Drainage. The concession is to operate and maintain the motorway portion of the tunnel, while the Malaysian government maintains ownership of the land and the tunnel itself. The Malaysian Highway Authority was the government agency which signed the concession agreement and is responsible for the technical regulation of the project.

\section{Implementation}

In 2003, construction commenced. The total cost of the SMART project was USD 510 million. The private sector provided a third of the total funds, with the Malaysian government expending USD340 million and the joint venture covering the remaining USD170 million. In order to recoup the capital investment and operating expenses, SMART Sdn Bhd charges a toll fee for private cars and light vans two Malaysian ringgits (USD0.63) for each use of the tunnel. The same toll rate is applied to taxis, but passengers pay the toll instead of the taxi operator. 


\section{Outcomes}

The SMART project faced its first test at the beginning of September 2007, when the motorway needed to be shut down for a major storm, when the Klang River registered a reading of 70 cubic meters per second. The motorway was then reopened within eight hours of being shut down. SMART Sdn Bhd was able to keep the water level below the flood level, preventing disturbances to the city centre. In addition to the effective management of flooding situations the tunnel has also helped to reduce congestion and cut down on travel time into the city centre between 10 to 15 minutes. These benefits present promising opportunities that could procure an effective reeponse to both climate change mitigation (emissions savings from improved traffic ) and adaptation (water management).

\section{Lessons learned and Recommendations}

The SMART Tunnel project is an innovative infrastructural project that combines a system of traffic dispersal and a flood mitigation initiative. By using a public-private partnership, the government was able to:

- Effectively lower its costs.

- Fasten the infrastructure development.

- Improved performance delivery through private sector efficiency.

Key recommendations with respect to this kind of innovative infrastructure project can be mainly related to the following aspects:

- Technically complex projects require time and specialist skills from public and the private sector.

- Project finance arrangements and risk pricing can result in potentially higher cost.

- Too high contracting could rule out many private investors and hence projects.

- Long term commitment requires a systematic budget planning.

- Effective monitoring over long concession period requires extensive knowledge and experience from both public and private actors. 


\section{The Ouarzazate project in Morocco}

\section{Overview and Stakeholders}

To meet the fast growing demand for electricity, Morocco will need to double its power generation capacity by 2020 . This substantial challenge is compounded by Morocco's high reliance on energy imports that currently account for $97 \%$ of total supply. Nonetheless, unlike many other developing countries, in Morocco private producers already generate more than $50 \%$ of the country's total electricity needs. Building on this, the government aims to make private production the cornerstone of its renewable energy installation programs. The USD 9 billion plan calls for the development of 2,000 MW by 2020, staring with the Ouarzazate facility (Noor I), based on a PPP model. A broad group of international, national, government and non-government stakeholders ${ }^{13}$ have been involved in the project.

\section{Application}

The building of the Ouarzazate facility aims to increase power generation from solar power and mitigate greenhouse gas emissions and local environment impacts as well as generating economic and social benefits (e.g. promoting green growth and local economic development, improving the country's energy security, shifting subsidies and the energy system away from fossil fuels).

\section{Design}

The implemented PPP model has enabled to tap into private-sector capital, technical expertise, and managerial efficiency. The partnership incorporates Power Purchase Agreements (PPAs), and sets the terms for a large amount of concessional finance provided by the Government of Morocco and International Finance Institutions (IFIs), some of which has been distributed via the Clean Technology Fund (CTF). The PPP is based on a Special Purpose Vehicle, namely a consortium of private developers and the Moroccan Agency for Solar Energy (MASEN). The Government of Morocco provided a substantial subsidy, in the form of the PPA covering the expected 25-year lifetime of the project. In addition, IFIs provided

${ }^{13}$ E.g. Moroccan ministry of Interior, the African Development Bank, The European Investment Bank, Moroccan private companies. 
the necessary institutional and specialized technical support. It is foreseen that the plant will have a capacity of between 125 and $160 \mathrm{MW}$ and will use the most mature CSP technology currently available.

\section{Implementation}

The lending instruments are represented by USD 200 million loan from the International Bank for Reconstruction and Development (IBRD) to MASEN (Solar Incremental Cost Support Component) and a USD 97 million Clean Technology Fund (CTF) concessional loan to MASEN (PPP Component). The CTF loan will be used for example for onlending by MASEN to the Solar Power Company (SPC) that will be setup with the competitively selected private partner to construct and operate the power plant. ${ }^{14}$ The CTF loan has a 40 year maturity, a 10 year grace period, a $0.25 \%$ per annum service charge and a one-time management fee of $0.25 \%$.

The IBRD loan will be used for so-called Component 2 of the Project, namely to assist MASEN in financing its power purchase agreement with the SPC, by partially covering the incremental cost of CSP over conventional power generating technologies. 15

\section{Outcomes}

The project aims to increase the country's energy security, gradually develop R\&D and green energy industries, as well as support interior regions of the country through creating jobs. It is also expected that solar technology will contribute to better integration of regional markets and substantial increase of green electricity trade. The final estimates on the technical performance of the plant have not been disclosed yet, though it is expected that the final bid results will be consistent with an expected annual power generation between 420 and $430 \mathrm{GWh} .{ }^{16}$

\footnotetext{
${ }^{14} \mathrm{http}$ //climatepolicyinitiative.org/wp-content/uploads/2012/08/Ouarzazate-I-CSP-Update.pdf 15 http://www-wds.worldbank.org/external/default/WDSContentServer/WDSP/IB/2011/07/26/ 000003596_20110727150020/Rendered/PDF/Project0Inform0sal0Stage0v070final.pdf

${ }^{16}$ http://climatepolicyinitiative.org/wp-content/uploads/2012/08/Ouarzazate-I-CSP-Update.pdf
} 


\section{Lessons learned and Recommendations}

This PPP allows the government to share costs and risks with international and private financiers and project developers. It also helps to drive overall costs down. The private developer bears construction and operational risk while the Government of Morocco bears electricity market risk (revenue risk). MASEN plays a central role acting as both equity investor and power purchaser (off-taker) and thus has the ability to align public and private objectives.

The project met numerous challenges stemming from the goal to attract concessional financing and initiate private sector participation in the development of a high cost technology. Success factors includes: ${ }^{17}$

- Conduction of a preliminary technological assessment to ensure the minimization of technical risks.

- Coordinated mobilization of donor co-financing to demonstrate the government's ability to gradually mobilize private sector contributions for solar power development.

- Implementation of a PPP model that ensures an efficient risk allocation.

- Introduction of a combination of capital and output subsidies to bring down initial costs while providing incentives for plant performance.

- Ensure investor interests through sound early market analyses

- Alignment of the size of the project to MASEN's ability to mobilize financing, to ensure project feasibility.

- Selection of the best procurement approach and conduction of transparent bidding process (in this case a two-stage bidding with prequalification) to satisfy clients' needs and raise their interest.

${ }_{17}$ Based on the WB document: http://www-wds.worldbank.org/external/default/WDSContentServer/WDSP/ IB/2011/07/26/000003596_20110727150020/Rendered/PDF/Project0Inform0sal0Stage0v070final.pdf 


\section{Appendix 2: Characteristics of PPPs}

An essential ingredient of PPPs is the contract formalising the relationship between public and private parties. The following typology, adapted from the Asian Development Bank (ADB, 2008), provides a useful overview of PPP types:

- Service contracts are typically short term (1-3 years) and used by public entities that wish to engage private parties to carry out specific tasks or services. Asset ownership remains in public hands and investments and risks are limited for private parties. Service contracts can form part of a public sector strategy to improve efficiency or to support private sector development.

- Management contracts extend the responsibility of private sector to the management of major components or of entire operations, typically over 2-5 years. Public entities retain overall ownership and private sector risks remain limited. Management contracts can be an intermediate step to more intense private sector involvement.

- Affermage or lease contracts award responsibility to private parties to manage, operate and in some cases carry out task/project renewals. Such contracts are typically medium-term (10-15 years) and imply shared commercial risk between public and private parties. They can be advantageous to public authorities to improve operational and commercial efficiency.

- Build-operate-transfer (BOT) contracts require investment in and operation of a major task by the private sector. Asset ownership can (partially) be transferred to private parties, which are required to contribute to financing and therefore to assume significant risk. BOT contract are common in infrastructure PPPs and can help mobilise additional financial resources.

- Concessions shift responsibility for all operation, financing and execution of specific investments to the private sector and typically involve longer term contracts (25-30 years). (Part of) asset ownership is transferred to private parties and concessions require 
significant private sector investment and risk-taking. In addition to potentially improving efficiency, concessions can contribute to mobilising additional finance.

- Joint ventures, lastly, refer to partnerships initiated and financed jointly by public and private parties. Asset ownership, investments and risks are shared and both parties have direct interest in the long-term success of the venture. Joint ventures have the ability to match private sector advantages with public sector social concerns.

Other key characteristics of PPPs are risk sharing and the - intimately linked - need to provide financial reward to the private sector. Ultimately, private sector investments will be made in attractive markets where the balance of risks and returns on investment meet the requirements of investors. Different types of private investors will prioritise different markets or targets and require different returns, as illustrated in the table below.

Table 1: Indicative returns and targets for different private investors

\begin{tabular}{lll} 
Investor type & Targets & Required returns \\
\hline Venture capital & Start-ups, new technologies, prototypes & $>50 \%$ IRR \\
Private equity & Pre IPO companies, demonstrator technologies & $35 \%$ IRR \\
Infrastructure funds & Proven technologies, private companies & $15 \%$ IRR \\
Pension funds & Proven technologies & $15 \%$ IRR \\
Bank mezzanine debt & Demonstrator / proven technologies, new companies & LIBOR + 700 bps \\
Bank senior debt & Proven technologies, established companies & LIBOR + 300 bps \\
\hline
\end{tabular}

Source: UNEP, 2009.

Understanding private actors and their relationship to markets is critical to ensure that effective PPP contracts are designed and implemented. The World Resources Institute (WRI) provides a simplified typology of private sector actors (WRI, 2012) differentiating between:

- Capital providers who make direct investments in projects (institutional investors, commercial banks, etc.).

- Market facilitators who provide critical financial services (insurance companies, financial institutions, liquidity providers, rating agencies, data providers, etc.).

- Project developers who undertake and seek project financing.

These actors will channel private capital in attractive markets and the WRI lists three key market characteristics that determine their attractiveness (ibid.): 
- Market liquidity, referring to the ability to buy and sell an asset, is desirable in increasing flexibility and chances to recover initial investments.

- Market scale, or the size of the market, will affect liquidity - larger markets being typically being more "liquid" - and larger markets offer more opportunity for diversification and hence reduced risk.

- Market transparency, or the availability of market data and information, which reassure investors and help close the gap between perceived and real risk.

In order to envisage PPPs, the right financial and policy instruments must be identified. The literature on mobilising and leveraging private climate finance provides basis from which to examine these different instruments and their relevance to PPPs in climate finance. The following tables present a typology of financial and policy instruments available to public authorities to leverage climate finance and information on their relevance to PPPs.

Table 2: Public financing instruments to leverage climate finance and relevance to PPPs

\begin{tabular}{|c|c|c|}
\hline Intervention types & Instruments and examples & Relevance to PPPs in climate finance \\
\hline Grants & $\begin{array}{l}\text { Instruments: Project- or company-level grants; } \\
\text { programme-level grants } \\
\text { Examples: grant for feasibility studies or } \\
\text { demonstration activities; interest subsidies. }\end{array}$ & $\begin{array}{l}\text { Grants are required in many contexts } \\
\text { but, as no return is expected, they are } \\
\text { largely risk free for the private sector } \\
\text { and thus not directly applicable to PPPs. }\end{array}$ \\
\hline Debt & $\begin{array}{l}\text { Instruments: Loans; credit lines; bonds; debt } \\
\text { funds; subordinated debt (mezzanine finance) } \\
\text { Examples: syndicated loans; export credit } \\
\text { loans; project bonds for LCR infrastructure; } \\
\text { green bonds; revolving funds for energy effi- } \\
\text { ciency; debt swaps; convertible debentures. }\end{array}$ & $\begin{array}{l}\text { Debt financing partnerships, for exam- } \\
\text { ple between governments and private } \\
\text { capital providers, can be implemented } \\
\text { to secure or increase the affordability } \\
\text { of finance (see the CDCF example in } \\
\text { Appendix 1). }\end{array}$ \\
\hline Equity & $\begin{array}{l}\text { Instruments: Direct equity investments; shares } \\
\text { in equity funds; preferred equity (mezzanine } \\
\text { finance) } \\
\text { Equity fund-of-funds ("umbrella funds") } \\
\text { Examples: preferred stocks in companies } \\
\text { developing/implementing LCR activities, direct } \\
\text { equity in LCR projects. }\end{array}$ & $\begin{array}{l}\text { Equity financing partnerships can for } \\
\text { example involve public authorities and } \\
\text { project developers and be implement- } \\
\text { ed for (energy) infrastructure projects. }\end{array}$ \\
\hline De-Risking & $\begin{array}{l}\text { Instruments: Insurances; guarantees; deriva- } \\
\text { tives } \\
\text { Examples: on-line insurance; loan or equity } \\
\text { guarantees; political, regulatory, credit risk, } \\
\text { export credit guarantees; swaps (interest, } \\
\text { exchange, credit default); structured products } \\
\text { including asset-backed securities, weather- } \\
\text { indexed derivatives. }\end{array}$ & $\begin{array}{l}\text { Risk being at the core of PPPs, de- } \\
\text { risking instruments are pivotal to } \\
\text { ensuring their attractiveness to private } \\
\text { actors. }\end{array}$ \\
\hline
\end{tabular}

Source: Adapted after OECD, 2015. 
Table 3: Public policy instruments to leverage climate finance and relevance to PPPs

\begin{tabular}{|c|c|c|}
\hline Intervention types & Instruments and examples & $\begin{array}{l}\text { Relevance to PPPs in climate } \\
\text { finance and examples }\end{array}$ \\
\hline Policy & $\begin{array}{l}\text { Instruments: Laws and policies; plans and tar- } \\
\text { gets; standards; quotas } \\
\text { Examples: energy efficiency standards; market } \\
\text { creation (e.g. Clean Development Mechanism); } \\
\text { renewables purchase obligations; feed-in-tariffs; } \\
\text { advance market commitments; renewable ener- } \\
\text { gy certificate schemes; land-use planning; trade } \\
\text { policies and preferential treatment of LCR prod- } \\
\text { ucts and services. }\end{array}$ & $\begin{array}{l}\text { Many policies are relevant to ensure } \\
\text { adequate framework conditions are } \\
\text { in place. More information on the } \\
\text { policy framework of PPPs is provid- } \\
\text { ed in Box } 7 \text {. }\end{array}$ \\
\hline Fiscal Policy & $\begin{array}{l}\text { Instruments: Taxes; subsidies and tax re- } \\
\text { liefs/credits; market support } \\
\text { Examples: environmentally related taxes; pref- } \\
\text { erential tax treatment (e.g. accelerated deprecia- } \\
\text { tion) for LCR technologies; eliminating fossil-fuel } \\
\text { subsidies. }\end{array}$ & $\begin{array}{l}\text { Favourable fiscal policy can be an } \\
\text { effective way of channelling invest- } \\
\text { ments toward low carbon action and } \\
\text { for public authorities to secure } \\
\text { partnerships with private actors. }\end{array}$ \\
\hline $\begin{array}{l}\text { Information and } \\
\text { Innovation Policy }\end{array}$ & $\begin{array}{l}\text { Instruments: Research and development; licens- } \\
\text { es and patents; technology transfer; education } \\
\text { and awareness; data and statistics } \\
\text { Examples: R\&D for LCR technologies; bilateral } \\
\text { technology transfer agreements; technology } \\
\text { centres of excellence; labelling schemes; wind } \\
\text { speed or solar radiation mapping. }\end{array}$ & $\begin{array}{l}\text { PPPs can ensure R\&D funding is } \\
\text { available to private actors and make } \\
\text { its benefits available for public } \\
\text { authorities. }\end{array}$ \\
\hline
\end{tabular}

Source: Adapted after OECD, 2015.

As an example, the International Energy Agency (IEA), proposes three models for Energy Efficiency (EE) financing through PPPs, applicable to different market environments and involving different degrees of public and private involvement. Dedicated credit lines require greater amounts of public sector financing and are suitable for relatively immature markets. Risk-sharing facilities involve lesser amounts of public financing and are suitable to relatively mature markets. Lastly, energy saving performance contracts do not require direct public financing and are only applicable to mature markets. The following table provides additional information on the characteristics of these options. 
Table 4: Possible PPP models and features for energy efficiency financing

\begin{tabular}{|c|c|c|c|c|c|}
\hline \multirow[b]{2}{*}{$\begin{array}{l}\text { Type of } \\
\text { PPP }\end{array}$} & \multirow[b]{2}{*}{ Overview } & \multicolumn{4}{|c|}{ PPP features } \\
\hline & & $\begin{array}{l}\text { Contractual } \\
\text { agreement }\end{array}$ & $\begin{array}{l}\text { Risk alloca- } \\
\text { tion }\end{array}$ & $\begin{array}{l}\text { Private finance } \\
\text { mobilisation }\end{array}$ & $\begin{array}{l}\text { Private } \\
\text { sector re- } \\
\text { ward }\end{array}$ \\
\hline $\begin{array}{l}\text { Dedicated } \\
\text { credit lines }\end{array}$ & $\begin{array}{l}\text { - Mechanism under } \\
\text { which governments or } \\
\text { donors provide low- } \\
\text { interest loans to LFIs to } \\
\text { encourage them to } \\
\text { offer sub-loans to } \\
\text { implementers of EE } \\
\text { projects. }\end{array}$ & $\begin{array}{l}\text { Loan agree- } \\
\text { ment between } \\
\text { partners. }\end{array}$ & $\begin{array}{l}\text { Project fi- } \\
\text { nancing risk } \\
\text { shared be- } \\
\text { tween part- } \\
\text { ners. }\end{array}$ & $\begin{array}{l}\text { Private partner } \\
\text { generally pro- } \\
\text { vides co- } \\
\text { financing. }\end{array}$ & $\begin{array}{l}\text { LFI earns fee } \\
\text { by on-lending } \\
\text { funds at } \\
\text { higher inter- } \\
\text { est. }\end{array}$ \\
\hline $\begin{array}{l}\text { Risk- } \\
\text { sharing } \\
\text { facilities }\end{array}$ & $\begin{array}{l}\text { - Mechanism where } \\
\text { governments or multi- } \\
\text { lateral banks offer } \\
\text { guarantee product to } \\
\text { absorb some EE project } \\
\text { risks and encourage } \\
\text { involvement of LFIs in } \\
\text { EE financing by reduc- } \\
\text { ing their risk. }\end{array}$ & $\begin{array}{l}\text { Guarantee } \\
\text { Facility } \\
\text { Agreement } \\
\text { (GFA). }\end{array}$ & $\begin{array}{l}\text { Public part- } \\
\text { ner absorbs } \\
\text { some finan- } \\
\text { cial risk. }\end{array}$ & $\begin{array}{l}\text { Risk reduction } \\
\text { mobilises addi- } \\
\text { tional private- } \\
\text { sector financing. }\end{array}$ & $\begin{array}{l}\text { LFI earns } \\
\text { interest on } \\
\text { additional } \\
\text { loans mobi- } \\
\text { lized. }\end{array}$ \\
\hline $\begin{array}{l}\text { Energy } \\
\text { saving } \\
\text { perfor- } \\
\text { mance } \\
\text { contracts } \\
\text { (ESPCs) }\end{array}$ & $\begin{array}{l}\text { - ESCO enters into term } \\
\text { agreement with public } \\
\text { agency to provide } \\
\text { services, with pay- } \\
\text { ments contingent on } \\
\text { demonstrated perfor- } \\
\text { mance. }\end{array}$ & $\begin{array}{l}\text { Energy Ser- } \\
\text { vices Agree- } \\
\text { ment (ESA). }\end{array}$ & $\begin{array}{l}\text { Performance } \\
\text { risk generally } \\
\text { borne by } \\
\text { ESCO. }\end{array}$ & $\begin{array}{l}\text { ESCOs mobilize } \\
\text { private-sector } \\
\text { financing. }\end{array}$ & $\begin{array}{l}\text { Performance- } \\
\text { based pay- } \\
\text { ment. }\end{array}$ \\
\hline
\end{tabular}

Source: IEA, 2011. 



\section{Appendix 3: \\ Overview of selected PPP climate funds}

The following table provides an overview of a selection of climate funds operating under PPP models.

Table 1: Overview of selected climate funds built on PPP models

Name (Lead Authority) Key Characteristics

Green for Growth Fund (The European Investment Fund)

Community Development Carbon Fund (The World Bank)

The BioCarbon Fund (The World Bank)

Prototype Carbon Fund (The World Bank)
Stakeholders and funding: 2 governmental bodies, 7 international financial institutions, and 3 private investors, with a total outstanding portfolio of EUR 170 million, and total investor commitment of EUR 258 million.

Overview: Operational since 2009, the fund aims to enhance energy efficiency (EE) and foster renewable energies (RE) by (1) refinancing financial institutions (e.g. local commercial banks) and (2) providing direct financing to non-financial institutions (e.g. energy service companies).

Achievements: 176 thousand tons of $\mathrm{CO} 2$ and 671 thousand MWh saved annually.

Stakeholders and funding: 9 governments and 15 private firms, with a total capitalisation of USD 128.6 million.

Overview: Operational since 2003, the CDCF aims to promote projects achieving emission reductions and measurable social, environmental and economic benefits. It supports projects that measurably benefit poor communities, and which receive verified Kyotocompliant emission reductions in return via CDM and ERPA mechanisms.

Achievements: $69 \%$ of the capital allocated to the world's poorest countries, including $58 \%$ to LDCs. Portfolio comprising of 21 active CDM projects.

Stakeholders and funding: 1st Tranche: 4 governments and 10 private firms, with a total capital of USD 53.8 million; 2nd Tranche: 2 governments and 3 private firms with a total capital of 29.5 million.

Overview: Operational since 2004, the fund aims to mobilise financing to develop projects that sequester or conserve carbon in forest and agro-ecosystems, through purchases of land-based carbon emission reductions, which can then be used against obligations for emission reductions or for regulated/voluntary emission reduction regimes. Achievements: USD 90 million allocated to 25 projects that have restored 150,000 hectares of degraded lands and reduced deforestation in over 350,000 hectares of land.

Stakeholders and funding: 9 governments and 15 private companies with a total capital USD 180 million.

Overview: Operational since 2000, the main objective was to pioneer international development and emissions reduction projects in LDCs via CDM and JI mechanisms, investing contributions made by companies and governments in projects designed to produce emission reductions.

Achievements: 2010. ERPAs Signed and Active 133. USD 1.84 billion value and 228 million $\mathrm{tCO}_{2}$ Pipeline Projects 47, value USD 208 million equivalent to 53 million $\mathrm{tCO}_{2}$. 
Table 1 continued

\begin{tabular}{|c|c|}
\hline Name (Lead Authority) & Key Characteristics \\
\hline $\begin{array}{l}\text { Climate Public-Private } \\
\text { Partnership Fund (Asian } \\
\text { Development Bank) }\end{array}$ & $\begin{array}{l}\text { Stakeholders and funding: ADB and private companies operating in Asia, with commitment of } \\
\text { over USD } 919 \text { million to } 61 \text { private equity fund investments in Asia. } \\
\text { Overview: Operational since 2012, the fund supports projects in alternative energy generation, } \\
\text { resource efficiency, and nature-based assets and environmental services through the provision } \\
\text { of equity, debt, or grant financing. } \\
\text { Achievements: Active investments (vintage years 2001-2008) had generated a net return of } \\
9.73 \% \text { and a multiple of } 1.3 \text { times. }\end{array}$ \\
\hline $\begin{array}{l}\text { NEFCO Carbon Fund } \\
\text { (Nordic Environment } \\
\text { Finance Corporation) }\end{array}$ & $\begin{array}{l}\text { Actors: } 5 \text { public investors, and } 6 \text { private sectors investors with a capitalisation of EUR } 165.3 \\
\text { million by } 2011 \text {. } \\
\text { Overview: Operational since } 2008 \text {, the fund implements instrument to purchase GHG emissions } \\
\text { reduction from projects in RE, EE and fuel switching. It acts as a buyer of ERUs/CERs/AAUs } \\
\text { under CDM and JI mechanisms. } \\
\text { Achievements: During } 2013,1,214,850 \text { credits were delivered from projects in China, Vietnam } \\
\text { and Russia. }\end{array}$ \\
\hline $\begin{array}{l}\text { Danish Climate Invest- } \\
\text { ment Fund (KIF) (Danish } \\
\text { Government and IFU) }\end{array}$ & $\begin{array}{l}\text { Actors: The fund was eatblished by the Danish Government and Investment Fund for Develop- } \\
\text { ing Countries, in partnership with private parties including PensionDanmark, PKA and Pæda- } \\
\text { gogernes Pensionskasse, the private investment fund Dansk Vækstkapital and Aage V. Jensen } \\
\text { Charity. Foundation. } \\
\text { Overview: the fund has procured DKK } 1.4 \text { billion of public (DKK } 525 \text { million) and private (DKK } \\
774 \text { million) funds to offer risk capital and advice to climate action in developing countries in } \\
\text { Asia, Africa, Latin America and parts of Europe. The fund provides partial funding, requiring } \\
\text { additional funding from other public and private factors and, total funding for supported pro- } \\
\text { jects is estimated to be DKK } 8-9 \text { billion. } \\
\text { Achievements: To date, the fund has supported six projects in Kenya, China, the Maldives and } \\
\text { Brazil. }\end{array}$ \\
\hline
\end{tabular}

Source: Authors 
Nordic Council of Ministers

Ved Stranden 18

DK-1061 Copenhagen K

www.norden.org

\section{Public-Private Partnerships for Climate Finance}

There is strong evidence showing the urgent need for scalingup climate finance to mitigate greenhouse gases in line with the $2{ }^{\circ} \mathrm{C}$ target, and to support adaptation to safeguard the international community from the consequences of a changing climate. While public actors have a responsibility to deploy climate finance, it is clear that the contribution from the private sector needs to be significant. Consequently, a strong public commitment is needed to engage with the private sector and ensure climate finance is leveraged and deployed effectively. In this context, Public Private Partnerships (PPPs) are a promising avenue to contribute to climate finance delivery. PPPs provide frameworks to ensure public leadership and accountability in tackling climate change, while enabling the ownership of certain components of climate finance to be transferred to private hands.

TemaNord 2015:577

ISBN 978-92-893-4394-7 (PRINT)

ISBN 978-92-893-4395-4 (PDF)

ISBN 978-92-893-4396-1 (EPUB)

ISSN 0908-6692 